\title{
Estrogen Differentially Regulates Estrogen and Nerve Growth Factor Receptor mRNAs in Adult Sensory Neurons
}

\author{
Farida Sohrabji, Rajesh C. Miranda, and C. Dominique Toran-Allerand \\ Department of Anatomy and Cell Biology and Center for Reproductive Sciences, Columbia University College of \\ Physicians and Surgeons, New York, New York 10032
}

\begin{abstract}
We have previously shown that neurons in the basal forebrain colocalize the neurotrophin receptor $p 75^{\text {NGFr }}$ and estrogen receptors. The present study was designed to examine (1) if neural neurotrophin targets respond to estrogen as a general phenotypic feature and (2) if NGF receptor mRNAs are regulated by estrogen, using a prototypical target of NGF, the dorsal root ganglion (DRG) (sensory) neuron. We demonstrate, for the first time, the presence of estrogen receptor mRNA and protein (binding sites) in adult female rat DRG. Moreover, estrogen receptor mRNA expression, while present in DRG neurons from both the ovariectomized (OVX; estrogen deficient) and intact female rat, was downregulated, as in the adult CNS, during proestrus (high estrogen levels) and in OVX animals replaced with proestrus levels of estrogen, as compared to OVX controls. In contrast, although the mRNAs for the NGF receptors $\mathrm{p} 75^{\mathrm{NGFR}}$ and $t r k A$ were also expressed in DRG neurons from OVX and intact animals, expression of both NGF receptor mRNAs was upregulated in sensory neurons during proestrus, as compared to the OVX condition. Estrogen replacement, on the other hand, resulted in a transient downregulation of $\mathrm{p} 75^{\mathrm{NGFR}}$ mRNA and a time-dependent upregulation of trkA mRNA. Estrogen regulation of NGF receptor mRNA in adult peripheral neural targets of the neurotrophins supports the hypothesis that estrogen may regulate neuronal sensitivity to neurotrophins such as NGF and may be an important mediator of neurotrophin actions in normal neural function and following neural trauma.
\end{abstract}

[Key words: estrogen receptors, trkA mRNA, p75 ${ }^{\text {NGFR }}$ mRNA, dorsal root ganglia, proestrus, ovariectomy, estrogen replacement]

\footnotetext{
Received Apr. 9, 1993; revised July 16, 1993; accepted July 29, 1993.

We thank Dr. Luis F. Parada (Frederick Cancer Research and Development Center) for the generous gift of the pDM97 plasmid, Drs. Michel Ferin and Sharon Wardlaw (Columbia University) for assistance with the plasma estrogen assay, Dr. Neil J. MacLusky (University of Toronto) for guidance with the estrogenbinding assay, and Wayne D. L. Bentham and Lucinda Leung for skilled technical assistance at various stages of this project. We also thank Drs. Lloyd A. Greene, Thomas M. Jessell, and Sharon L. Wardlaw (Columbia University) for constructive comments and critical review of the manuscript. This work was supported in part by grants from NIH (AG-08099), NSF (BNS 87-00400 and IBN 91-09375), the American Health Assistance Foundation, Pilot grant from the Center for Alzheimer's Disease Research in New York (AGi-08702-03), an ADAMHA Kesearch Scientist Award (MH-00192) to C.D.T.-A., and a gift from the Maffei family. Milan. Italy. This work has been presented in part at the 21 st annual meeting of the Society for Neuroscience, New Orleans, LA, 1991.

Correspondence should be addressed to C. Dominique Toran-Allerand. Columbia University College of Physicians and Surgeons, 630 West 168 th Street, New York, New York 10032

Copyright $@ 1994$ Society for Neuroscience $0270-6474 / 94 / 140459-13 \$ 05.00 / 0$
}

Exposure to estrogen profoundly influences developing neural cytoarchitecture and organization, as well as the expression and maintenance of neuroendocrine and behavioral functions and systems in adulthood. Growth- (neurite-) promoting effects of estrogen were first demonstrated in organotypic explant cultures of the developing rodent hypothalamus, prcoptic area, and cerebral cortex (Toran-Allerand, 1976, 1980, 1984; Toran-Allerand et al., 1980, 1983), and subsequently confirmed in the developing brain in situ (Nishizuka and Arai, 1981; Hammer and Jacobson, 1984; Stanley and Fink, 1986; Stanley et al., 1986; Lustig et al., 1991) or as transplants in the eyc (Nishizuka and Arai, 1982) or brain (Matsumoto et al., 1988) of adult hosts, as well as in estrogen target regions of the deafferented (Matsumoto and Arai, 1981) or steroid-deprived (Frankfurt et al., 1990) adult CNS.

Estrogen regulates the transcription of a variety of cytoskeletal proteins (Guo and Gorski, 1988; Lustig et al., 1991), steroid, peptide, and neurotransmitter receptors (Dohanich et al., 1982; MacLusky and McEwen, 1978; DeKloet et al., 1986), as well as hormones and neuropeptides (Wilcox and Roberts, 1985; Romano et al., 1988), although the mechanism of estrogen action on many of its target genes is poorly understood. The estrogen receptor is a member of the superfamily of steroid/thyroid hormone/vitamin $\mathrm{D}_{3} /$ retinoic acid reccptors capable of activating genes by directly binding DNA sites containing hormone-specific regulatory elements (Evans, 1988; Beato, 1989; O’Malley, 1990). An estrogen response element (ERE) has been identified in several estrogen-responsive genes including vitellogenin (Klein-Hitpass et al., 1986), c-fos (Weiš and Rosales, 1990), prolactin (Watermann et al., 1988), and $\beta$-luteinizing hormone (Shupnik and Rosenzweig, 1991), suggesting that, in some instances, steroid effects may be mediated through direct activation of relevant genes. Alternatively, estrogen-inducible genes may be regulated through intermediate steps via interactions with, or secondary activation of, endogenous transcription-regulating growth factors or their receptors, such as the neurotrophin family of NGF-related peptides and their receptors. Analysis of the identified promoter region (Sehgal et al., 1988) of the $\mathrm{p} 75^{\mathrm{NGFR}}$ (Toran-Allerand et al., 1992a) and 5'-flanking region of the trkA genes indicates the presence of sequences with a high degree of homology to the putative vitellogenin and c-fos EREs (Fig. 1), consistent with the hypothesis that, in some instances, estrogen may regulate steroid-inducible genes through interactions with the neurotrophins or their receptors.

Two NGF receptors have been described. The $75 \mathrm{kDa}$ protein p75 NiFr (Chao et al., 1986; Johnson et al., 1986; Radeke et al., 1987) has been shown to bind with low affinity at least three members of the neurotrophin family; NGF, brain-derived neu- 


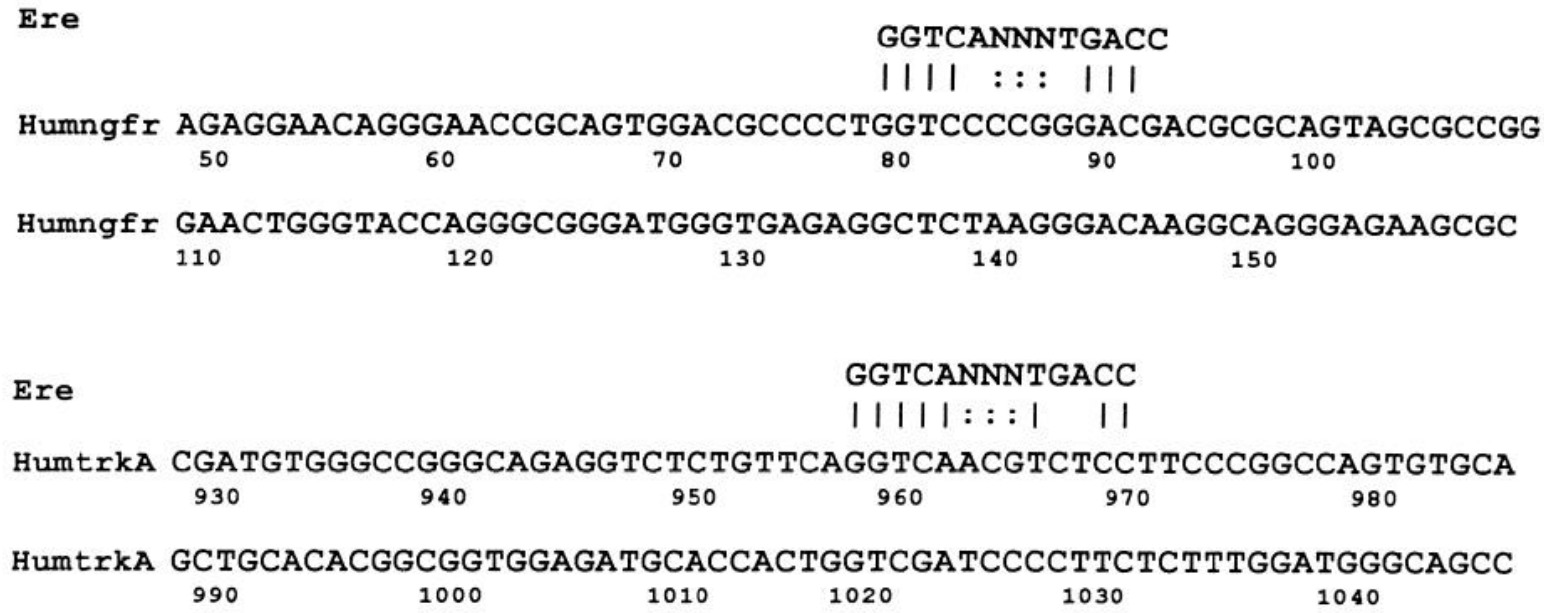

Figure 1. ERE-like sequences in $\mathrm{p} 75^{\mathrm{NGFR}}$ and trkA genes. Computer-assisted comparison of the 13 base palindromic ERE sequence (described for vitellogenin and c-fos genes) and the NGF receptor genes revealed close homology to sequences in the promoter region of the p75 $5^{\mathrm{NGFR}}$ gene and the $5^{\prime}$ region flanking the trk oncogene breakpoint in the trkA gene. Homologous nucleotides are indicated by vertical bars. Humngfr, human p $75^{\text {NGFR }}$ sequence; HumtrkA, human trkA sequence.

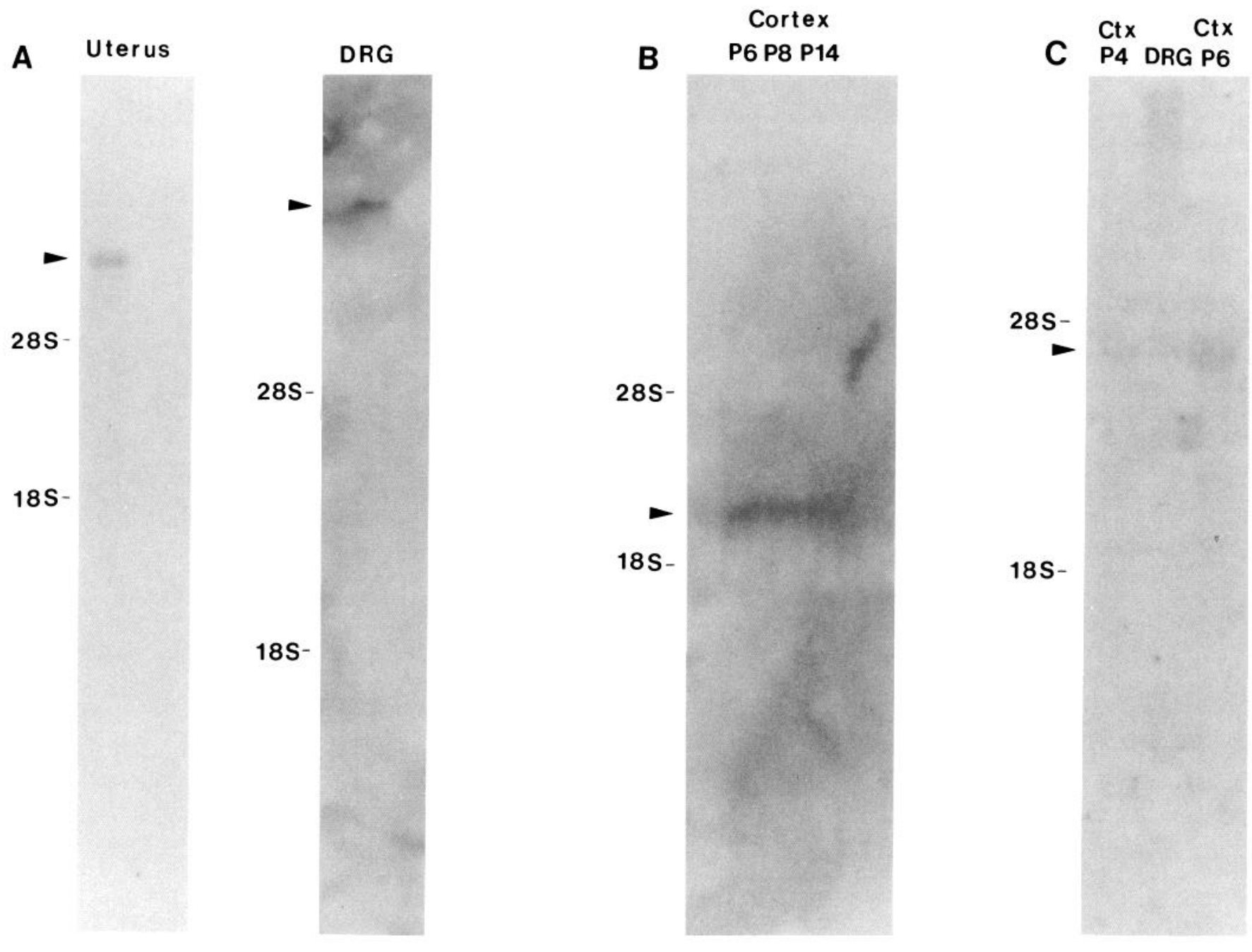

Figure 2. Specificity of oligonucleotide probes. Specificity of the oligonucleotide probes for the estrogen receptor, p75 ${ }^{\mathrm{NGFR}}$, and $t r k A$ was determined by Northern blot analysis of total RNA. A, Hybridization of the estrogen receptor probe to a single (arrowhead) transcript (6.5 kb) in rat uterus and DRG RNA. B. Hybridization of the trkA oligonucleotide probe to a single (arrowhead) transcript ( $3.2 \mathrm{~kb})$ in mouse cortex RNA, aged postnatal day (P) 6, P8, and P14. C. Hybridization of the p75 ${ }^{\text {NGFR }}$ oligonucleotide probe to a single (arrowhead) transcript ( $\left.3.8 \mathrm{~kb}\right)$ in P4, P6 mouse cortex and rat DRG RNA. 

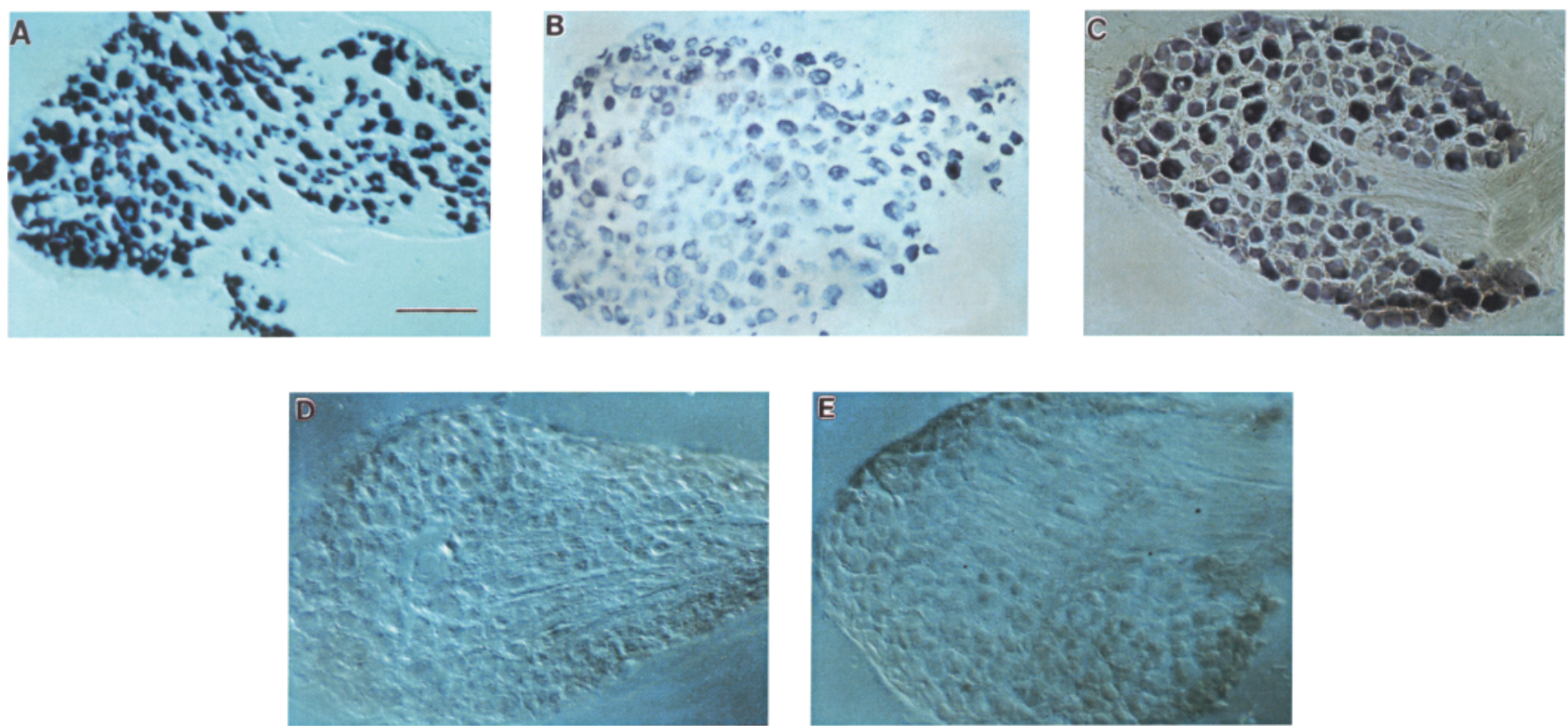

Figure 3. $A-E$, Estrogen receptor mRNA expression in DRG neurons. Twenty micrometer cryostat sections through DRG of intact and OVX females were hybridized to a 48 base digoxigenin-labeled oligonucleotide probe for the estrogen receptor. Note that the extent of hybridization to this probe was much greater in sensory neurons of the OVX female $(A)$ than the intact female during proestrus $(B)$ or the OVX female replaced with estrogen for $52 \mathrm{hr}(C)$. D, Control for hybridization specificity; DRG sections (from OVX animals) incubated with the estrogen receptor probe after prior incubation with a 90 base oligonucleotide, overlapping the 48 base experimental probe, were always unstained. $E$. Immunohistochemical control; DRG sections from OVX animals hybridized with the noncomplementary (sense) oligonucleotide were also unstained. $A$, $C, D$, and $E$ were photographed with Nomarski optics; $B$, bright-field photograph. Scale bar, $100 \mu \mathrm{m}$.

rotrophic factor, and neurotrophin-3. Neurotrophin signal transduction, however, appears to require the neurotrophins to associate with members of the tyrosine kinase receptor family of proto-oncogene products, $\operatorname{trk} A$ (gp140 ${ }^{\text {trk }}$ ) (Kaplan et al., $1991 \mathrm{a}, \mathrm{b})$ and the structurally related genes $\operatorname{trkB}$ (Soppet et al., 1991; Squinto et al., 1991) and $\operatorname{trkC}$ (Lamballe et al., 1991).

We have recently shown that estrogen receptor systems colocalize with p75 ${ }^{\mathrm{NGFR}} \mathrm{mRNA}$ and protein and trkA mRNA in neurons of the developing rodent medial septum, vertical and horizontal limbs of the nuclei of the diagonal band, substantia innominata, and nucleus basalis of Meynert (Toran-Allerand et al., 1992a; Miranda et al., 1993), as well as the cerebral cortex, striatum (caudate/putamen), and hippocampus (Miranda et al., 1993), regions previously described as targets of both NGF (Taniuchi et al., 1986; Yan and Johnson, 1987, 1988; Eckenstein, 1988; Koh and Loy, 1989; Mobley et al., 1989) and estrogen (Loy et al., 1988; Toran-Allerand et al., 1992b). The widespread colocalization of $\mathrm{p} 75^{\mathrm{NGFR}}$ with estrogen-binding sites suggested that the central and peripheral targets of the neurotrophins may respond to estrogen as a general phenotypic characteristic. To address this issue we investigated the presence of estrogen receptor mRNA and estrogen-binding sites in a prototypical peripheral target of NGF, the dorsal root (sensory) ganglion (DRG) neuron of the adult female rat. DRG neurons are dependent on NGF for their survival during development (Barde, 1980; Johnson et al., 1980; Thoenen and Barde, 1980; Eichler and Rich, 1989) but only following injury in adulthood (Csillick, 1987; Lindsay, 1988; Rich et al., 1989). Neither estrogen receptor protein nor its mRNA has previously been demonstrated in DRG neurons, or indeed in other peripheral ganglia, although neurons of the superior cervical ganglia (SCG; Wright and Smollen, 1983a,b), hypogastric ganglion, and the major pelvic ganglia (Melvin and Hamill, 1986, 1989) have been reported to be sensitive to gonadal steroids.

We also addressed the general question of whether colocalization of estrogen and neurotrophin receptor mRNAs implies the potential for regulatory interactions, by examining whether estrogen responsiveness in DRG neurons would be manifested functionally as an effect of this gonadal hormone on neurotrophin receptor gene expression. In the present study, we first compared NGF receptor mRNA expression in DRG of ovariectomized (OVX; estrogen deficient) and intact animals at proestrus (physiologically high estrogen levels) and found that not only are estrogen receptor mRNA and estrogen-binding sites present in adult female rat DRG neurons but that the expression of the mRNAs for the estrogen receptor and the two NGF receptors p75 NGFR and trkA is differentially modulated by the ovarian status of the animal. To assess directly the action of estrogen itself on NGF receptors mRNAs, we further compared OVX animals with those replaced with estrogen levels comparable to the morning of proestrus, and found a time- and receptor-specific regulation of NGF receptor mRNAs by estrogen. Our data support the hypothesis that the actions of estrogen on some target genes may involve intermediate steps, by modulating other transcription-regulating factors such as the neurotrophin receptors.

\section{Materials and Methods}

\section{Tissue samples}

Dorsal root ganglia were obtained from intact, OVX, and estrogentreated OVX adult female rats (Sprague-Dawley, Zivic-Miller, Allison Park, PA). All animals were maintained in a $14 \mathrm{hr}: 10 \mathrm{hr}$ light/dark cycle and given food and water ad libitum.

Proestrus/OVX study. The estrus cycle of intact females $(n=8)$ was monitored for at least 2 weeks ( $3-4$ cycles) before use and animals were 
killed between 1:00 and 2:00 P.M. on the day of proestrus (determined by vaginal smears). Bilaterally ovariectomized females were housed for $10 \mathrm{~d}$ before death and handled daily.

Estrogen replacement study. Bilaterally OVX animals purchased from Zivic-Miller (Allison Park, PA) were housed for $10 \mathrm{~d}$ before the experiment. They were then injected, subcutaneously, with $10 \mu \mathrm{g}$ of estradiol benzoate in sesame oil (10:00 A.M., day 1), and killed 4 hr (2:00 P.M., day 1) or $52 \mathrm{hr}$ later (2:00 P.M., day 3). Controls were injected with vehicle (sesame oil) only.

For in situ hybridization histochemistry, animals ( $n=5$ /group) were anesthetized with pentobarbital $(0.5 \mathrm{ml} / 100 \mathrm{gm})$ and perfused transcardially with isotonic saline, followed by $4 \%$ paraformaldehyde, containing $2.5 \%$ dimethyl sulfoxide (Sigma) and $0.1 \%$ diethyl-pyrocarbonate (Sigma), an RNase inhibitor. Cervical and lumbar ganglia were removed and postfixed for $2 \mathrm{hr}$ in the same fixative. Tissue was allowed to sucroseequilibrate overnight [15\% sucrose in phosphate-buffered saline (PBS)] and embedded in Ml embedding matrix (Lipshaw). Cryostat sections $(20 \mu \mathrm{m})$ were thaw mounted onto gelatin/polylysine-coated slides and processed immediately for in situ hybridization histochemistry. For RNA preparation, animals (OVX/proestrus, $n=3$ /group; estrogen replacement, $n=5$ /group) were anesthetized (as before), the spinal column exposed, and cervical and lumbar DRGs gathered immediately into liquid nitrogen. DRGs were stored at $-70^{\circ} \mathrm{C}$ until use.

\section{Preparation of oligonucleotide probes}

Complementary ("antisense") and noncomplementary ("sense") oligonucleotide sequences were synthesized on an Applied Biosystems 380B DNA Synthesizer (Protein Core, Columbia University/Howard Hughes Medical Institute).

Estrogen receptor. A previously described (Miranda and Toran-Allerand, 1992) 48 base oligonucleotide sequence was used, corresponding to nucleotides 1923-1970 in the ligand-binding domain of the uterine estrogen receptor (Koike et al., 1987) with less than $25 \%$ homology with the other members of the stcroid receptor superfamily of DNA-binding proteins.

NGF receptor: (1) For $\mathrm{p} 75^{\mathrm{NGFR}}$, a previously reported (Ernfors et al., 1988; Toran-Allerand et al., 1992a), 46 base sequence from the putative membrane-spanning domain of the sequenced receptor in the chick, corresponding to nucleotides 807-852 of the rat homolog (Radeke et al., 1987) was used. (2) For trkA, a unique 60 base oligonucleotide sequence directed against nucleotides 208-267 in the putative extracellular domain of the human cDNA sequence (Martin-Zanca et al., 1989), corresponding to a region of the mouse $t r k A$ first exon (Martin Zanca et al., 1990), was used to detect $t r k A$ mRNA.

Complementary and noncomplementary oligonucleotide probes were $3^{\prime}$ end-labeled with digoxigenin-deoxyuridine-triphosphate (dig-dUTP; an average of 4 molecules/tail), using terminal deoxynucleotidyl transferasc (Bcthesda Rescarch Labs) as previously described (Miranda and Toran-Allerand, 1992; Toran-Allerand and Miranda, 1992). Labeled probes were purified by sodium acetate/ethanol precipitation and diluted with TES buffer ( $10 \mathrm{~mm}$ Tris- $\mathrm{HCl}, 1 \mathrm{~mm}$ EDTA, $0.1 \%$ SDS, $\mathrm{pH}$ 8.0).

\section{In situ hybridization histochemistry}

In situ hybridization was performed according to the procedure described in Miranda and Toran-Allerand (1992). Briefly, sections were dehydrated in increasing ethanol grades, rehydrated without drying and rinsed for $5 \mathrm{~min}$ in $1 \times \mathrm{SSC}(0.15 \mathrm{M} \mathrm{NaCl}, 0.015 \mathrm{~m}$ sodium citrate, $\mathrm{pH}$ 7.2). Sections were prehybridized in a buffer containing $50 \%$ formamide, $1 \mathrm{M} \mathrm{NaCl}, 1 \times$ Denhardt's solution, $10 \mathrm{~mm}$ dithiothreitol (in $0.01 \mathrm{M}$ sodium acetate, $\mathrm{pH} 5.2$ ), and $0.5 \mathrm{mg} / \mathrm{ml}$ tRNA for $2 \mathrm{hr}$ at room temperature. Sections were then incubated $16-18 \mathrm{hr}$ with the oligonucleotide probe (diluted $20 \mathrm{ng} / \mathrm{ml}$ in the above buffer) at $42^{\circ} \mathrm{C}$, rinsed twice in $1 \times \mathrm{SSC}$, washed for $2 \mathrm{hr}$ in either $0.2 \times \mathrm{SSC}$ at $42^{\circ} \mathrm{C}$ (estrogen receptor and $\mathrm{p} 75^{\mathrm{NG} F \mathrm{Fr}}$ probes) or in $0.1 \times \mathrm{SSC}$ at $60^{\circ} \mathrm{C}$ (trkA probe), and washed overnight $\left(42^{\circ} \mathrm{C}\right)$ in $1 \times$ SSC. Tissue sections were then blocked for 30 min with 5\% nonfat dry milk (Carnation) in Tris-buffered saline (TBS; $10 \mathrm{~mm}$ Tris, $140 \mathrm{~mm} \mathrm{NaCl}, \mathrm{pH} 7.4$ ) containing $0.3 \%$ Triton $\mathrm{X}-100$ and then incubated in a 1:500 dilution of the polyclonal sheep anti-digoxigenin antibody, rab fragment, conjugated to alkaline phosphatase (Boehringer Mannheim) prepared in the blocking solution, for $48 \mathrm{hr}$ at $4^{\circ} \mathrm{C}$. Sections were washed three times for $15 \mathrm{~min}$ in TBS and soaked for $5 \mathrm{~min}$ in buffer $\mathrm{A}\left(100 \mathrm{nM}\right.$ Tris, $200 \mathrm{~mm} \mathrm{NaCl}$, and $50 \mathrm{~mm} \mathrm{MgCl}_{2}$, pH 9.5). Hybrids were visualized with a color reaction catalyzed by antibody-conjugated alkaline phosphatase, using nitroblue tetrazolium salt $(0.225 \mu \mathrm{g} / \mathrm{ml})$ and 5-bromo-4-chloro-3-indolyl-phosphate $(0.175$ $\mu \mathrm{g} / \mathrm{ml}$ ) as substrates in buffer $\mathrm{A}$, with $0.24 \mathrm{mg} / \mathrm{ml}$ levamisole to inhibit endogenous alkaline phosphatase activity. The color of the alkaline phosphatase reaction product depends critically on the $\mathrm{pH}$ of the substrate buffer (A), and can vary from a blue-purple $(\mathrm{pH} \mathrm{9.5)} \mathrm{to} \mathrm{a} \mathrm{brown-}$ black (pH 7.5-8.0) coloration. For any given probe, one animal each from the following comparison groups was run concurrently, that is, proestrus/OVX or OVX + vehicle/OVX $+4 \mathrm{hrE} / \mathrm{OVX}+52 \mathrm{hrE}$. Color development was closely monitored, and the reaction was terminated for all groups ( 5 min in $10 \mathrm{~mm}$ Tris + $1 \mathrm{~mm}$ EDTA), when color appeared fully developed in one condition. Slides were dehydrated briefly through ethanol grades, cleared in Histoclear (National Diagnostics), and coverslipped in Permount. Hybridization and immunohistochemical controls for the estrogen receptor oligonucleotide are described in Results. Extensive controls, ensuring the specificity of the nonisotopic in situ hybridization method and the probes used here, are described in Miranda and Toran-Allerand (1992) and Toran-Allerand and Miranda (1993).

\section{Hybridization specificity of oligonucleotide probes}

Hybridization specificity of each oligonucleotide probe was characterized by Northern blot analysis. Total RNA, prepared by a modification (Lu et al., 1989) of the Chomczynski and Sacchi (1986) method, was size fractionated on a $1.2 \%$ agarose denaturing gel and capillary transferred to nylon membrane (Hybond-N, Amersham). Filters were prehybridized overnight at $42^{\circ} \mathrm{C}$ in $4 \times$ SSPE, $40 \%$ formamide, $5 \%$ dextran sulfate, $25 \mu \mathrm{g} / \mathrm{ml}$ salmon sperm DNA, $100 \mu \mathrm{g} / \mathrm{ml}$ tRNA, $0.04 \times$ Denhardt's solution, and $0.2 \%$ SDS. The probes were 5 ' end-labeled with $\gamma$ - $^{3} \mathrm{P}$-ATP, using T4-polynucleotide kinase, and hybridization was performed at $42^{\circ} \mathrm{C}$ for $24 \mathrm{hr}$. Washes were performed under conditions of gradually increasing stringency $(4 \times$ SSC to $0.2 \times$ SSC, and from room temperature to $50^{\circ} \mathrm{C}$ ). Nylon membranes were apposed to Kodak X-Omat film between intensifying screens at $-80^{\circ} \mathrm{C}$ for $1-4 \mathrm{~d}$.

Northern analysis of total rat uterine RNA probed with the estrogen receptor oligonucleotide probe revealed hybridization to a single transcript (Fig. $2 A$ ) of the previously reported size [6.5 kilobases (kb) Koike et al., 1987]. A similar-sized transcript was seen in RNA obtained from OVX rat DRG. The 46 base p75 NGFR oligonucleotide sequence was identical to that reported by Ernfors et al. (1988), and Northern blot analysis of DRG-derived mRNA probed with this oligonucleotide revealed hybridization to the expected single transcript, approximately $3.8 \mathrm{~kb}$ in size (Fig. $2 C$ ). Total RNA probed with the oligonucleotide probe for $\operatorname{trk} A$ showed a single band of hybridization (Fig. $2 B$ ) to a 3.2 kb transcript (Martin-Zanca et al., 1989).

\section{Northern blot analysis}

Total RNA was size fractionated (10-25 $\mu \mathrm{g} /$ lane) on a $1.2 \%$ agarose, $18 \%$ formaldehyde gel and capillary transferred to nylon membrane (Hybond-N, Amersham). Filters were prehybridized (4-18 hr) and hybridized $(36-40 \mathrm{hr})$ at $37^{\circ} \mathrm{C}$ in $50 \%$ formamide, $3 \times \mathrm{SSC}, 0.1 \mathrm{M}$ Tris, $5 \times$ Denhardt's, and $10 \%$ dextran sulfate. Probes were labeled with $\alpha^{-32} \mathrm{P}_{-}$ $\mathrm{dCTP}$, using a random priming kit (Boehringer Mannheim). TrkA mRNA was identified by hybridization with pDM97, a 450 base pair (bp) trkAspecific probe corresponding to the extracellular and transmembrane domains of the trkA gene (Martin-Zanca et al., 1989; gift of L. F. Parada). p $75^{\text {NGifR }}$ was probed by hybridization with $\mathrm{p} 5 \mathrm{~b}$, a $2 \mathrm{~kb}$ probe corresponding to the extracellular domain of the p75 ${ }^{\mathrm{NiFR}}$ (Buck et al., 1988). Blots were washed in $0.2 \times \mathrm{SSC}$ and $0.5 \%$ SDS, briefly at room temperature first and then for $2 \mathrm{hr}$ at $60^{\circ} \mathrm{C}$, with frequent changes. Filters were then exposed to film (Kodak X-Omat) between intensifying screens and stored at $-70^{\circ} \mathrm{C}$ for $1-4 \mathrm{~d}$ before developing.

Using a standard morphometrics package (Jandel Scientific), optical density measurements were obtained from $\mathrm{x}$-ray film. $t r k A$ and $\mathrm{p} 75^{\mathrm{NGFR}}$ transcript densities were normalized to an internal control to account for variation in the amount of RNA loaded. Since estrogen has been reported to enhance the expression of commonly used controls such as $\beta$-actin (Guo and Gorski, 1988) and 28 S (Jones et al., 1986), but not $18 \mathrm{~S}$, ribusomal RNA (Yu et al., 1991), NGF receptor transcripts in this study were normalized to $18 \mathrm{~S}$ ribosomal RNA bands, visualized by ethidium bromide or by a riboprobe specific for $18 \mathrm{~S}$ (Ambion, Austin, TX). Group differences for the proestrus/OVX experiments were evaluated using a $t$ test while group differences for the estrogen replacement study were evaluated using a one-way ANOVA, with Student-NewmanKeuls test of planned post hoc comparisons. Differences were considered significant at the 0.05 level. 


\section{Estrogen receptor binding assay}

Estrogen-binding sites were identified by a modification of the nuclear exchange assay (MacLusky et al., 1990). Ten days after surgery, bilaterally ovariectomized and adrenalectomized rats (Sprague-Dawley, Charles River, Kingston, NY) were deeply anesthetized (pentobarbital, $0.5 \mathrm{ml} / 100 \mathrm{gm}$ ) and their (cervical/lumbar) DRGs removed and collected in ice-cold medium [Dulbecco's minimum essential medium (MEM), $0.65 \%$ glucose, $25 \%$ gelded horse serum). Ganglia were crudely freed of meningeal tissue and basement membrane and incubated with a $2 \mathrm{~nm}$ concentration of the synthetic estrogen $11 \beta$-methoxy- ${ }^{3} \mathrm{H}$-moxestrol (R2858; Du Pont-New England Nuclear; specific activity, $80 \mathrm{Ci} /$ mmol; $n=3)$, for $2 \mathrm{hr}$ at $37^{\circ} \mathrm{C}(n=3)$. For some animals $(n=2)$, DRG were incubated with $2 \mathrm{nM} 16 \alpha^{-125}$ I-iodo-3,17 $\beta$-estradiol (specific activity, $2200 \mathrm{Ci} / \mathrm{mmol}$; Du Pont-New England Nuclear). In all cases, half the ganglia harvested were incubated with the radioligand in the presence of $2 \mu \mathrm{M}$ unlabeled estrogen (17 $\beta$-estradiol or diethylstilbestrol, DES). After incubation, DRG were washed three times in ice-cold MEM + $0.1 \% \mathrm{BSA}$, for $5 \mathrm{~min}$ each, transferred to a homogenizer (clearance, $0.125 \mathrm{~mm}$ ), and homogenized in $300 \mu \mathrm{l}$ of a $1 \mathrm{~mm}$ potassium phosphate, $3 \mathrm{~mm}$ magnesium chloride, and $0.25 \%$ Triton $\mathrm{X}-100(\mathrm{pH} 6.5)$ solution. The homogenate was centrifuged briefly to recover a pellet and washed twice in the same buffer without Triton X-100. Pellets were then eluted with $1 \mathrm{ml}$ of $95 \%$ ethanol (estrogen is fully soluble in $>50 \%$ ethanol), and the radioactivity counted in a liquid scintillation counter. Pellets were dried and resuspended in $1 \times$ TE ( $10 \mathrm{~mm}$ Tris, $1 \mathrm{~mm}$ EDTA) and assayed fluorometrically for DNA content, using the Hoechst dye 33258 (Cesarone et al., 1979). Specific binding was determined as the difference between total binding and nonspecific binding (in the presence of an unlabeled competing ligand), and the data are expressed as femtomoles of specifically bound ligand/mg DNA.

To demonstrate specificity of estrogen binding sites in DRG neurons, additional experiments were performed using four groups of DRG. DRG were harvested as before and incubated in phenol red-free RPMI 1640 media supplemented with $25 \%$ gelded horse serum with ${ }^{3} \mathrm{H}$-moxestrol alone or ${ }^{3} \mathrm{H}$-moxestrol and $2 \mu \mathrm{M}$ DES, or the nonestrogenic hormones dihydrotestosterone (DHT) or progesterone. All subsequent analyses were as described before.

\section{Estrogen assay}

Circulating estrogen levels were assayed from the plasma of proestrus and untreated/estrogen-treated OVX animals. Blood was obtained from the internal carotids of deeply anesthetized (pentobarbital, $0.5 \mathrm{ml} / 100$ $\mathrm{gm})$ animals and collected in ice-cold, heparin-coated vials. Samples were then spun on a clinical centrifuge for $10 \mathrm{~min}$, and the supernatant (plasma) stored at $-20^{\circ} \mathrm{C}$ until assayed. Estrogen content was determined by a solid-phase ${ }^{125} \mathrm{I}$ radioimmunoassay (Diagnostic Products, Los Angeles, CA).

\section{Results}

\section{Estrogen receptor $m R N A$ and estrogen binding sites are} present in adult DRC

Estrogen receptor mRNA expression was found in virtually all DRG neurons of the intact and OVX animal, using nonisotopic (digoxigenin) in situ hybridization histochemistry with an oligonucleotide probe (Miranda and Toran-Allerand, 1992) to the ligand-binding domain of the rat uterine estrogen receptor. The staining intensity of the hybridization product appeared strongest in ganglion neurons obtained from OVX rats. As seen in Figure 3.1, all large and small neurons in the ganglion hybridized the probe, as evidenced by the dark blue/purple cytoplasmic reaction product. Nuclei generally remained unstained. However, although hybridization was characteristically restricted to the cytoplasm, alkaline phosphatase results in a flocculent reaction product, and where the probe hybridized abundantly, as in this instance, overstaining makes the nucleus less readily apparent. Non-neuronal cells, such as satellite cells and fibroblasts, did not hybridize the estrogen receptor probe, although occasional hybridization was seen in Schwann cells, and there was no hybridization signal in neuropil and axon bundles.
The estrogen receptor probe used here is highly specific for the estrogen receptor (Miranda and Toran-Allerand, 1992) and, by Northern blot analysis, recognizes a band of approximately $6.5 \mathrm{~kb}$ (Koike et al., 1987) in rat uterine RNA and DRG RNA from OVX rats (Fig. $2 A$ ). To ensure that the reaction product was the result of specific hybridization to the oligonucleotide, some sections were incubated with the estrogen receptor probe after prior incubation in a 100-fold excess of an unlabeled, 90 base oligonucleotide (deduced amino acids 564-593) that completely overlapped the 48 base experimental probe. These sections always remained unstained (Fig. 3D). As an immunohistochemical control, some sections from each DRG were hybridized with a noncomplementary ("sense") oligonucleotide and, as seen in the representative example in Figure $3 E$, these scctions always remained unstained, indicating a lack of hybridization.

A modification of the nuclear exchange assay (MacLusky et al., 1990; see Materials and Methods) was used to determine the presence of estrogen-binding sites in sensory ganglia. In these experiments, DRG were obtained from ovariectomized and adrenalectomized rats to minimize receptor occupancy by any endogenous estrogen. Similar levels of competable binding were seen using either $16 \alpha^{-125} 1$-iodo-3, $17 \beta$-estradiol $(31.36 \mathrm{fmol} / \mathrm{mg}$ DNA) or $11 \beta$-methoxy- ${ }^{3} \mathrm{H}$-moxestrol $(39.43 \mathrm{fmol} / \mathrm{mg} \mathrm{DNA})$, with a mean specific nuclear binding of $34.5( \pm 8.58) \mathrm{fmol} / \mathrm{mg}$ DNA. The nonestrogenic ligands DHT and progesterone were not able to compete moxestrol binding, suggesting that binding was specific to the estrogen receptor. Since estrogen receptor mRNA localized primarily to sensory neurons, specific binding in these ganglia suggests that estrogen receptor mRNA is translated into its encoded protein in these neurons.

\section{Ovarian hormones downregulate estrogen receptor $m R N A$ in $D R G$ neurons}

Not only was estrogen receptor mRNA present in all DRG ncurons, but the extent of hybridization to the estrogen receptor probe appeared to be regulated by the estrogen status of the animal. In the OVX rat (Fig. $3 A$ ) the pattern of hybridization (staining) was virtually homogeneous within a ganglion. Thus, in the estrogen-deficient state, every DRG neuron appeared to express estrogen receptor $\mathrm{mRNA}$ strongly. In plasma obtained from OVX animals $11 \mathrm{~d}$ after gonadectomy, estrogen levels were below sensitivity of the assay ( $<8 \mathrm{pg} / \mathrm{ml}$; see Fig. 4). In contrast, on the afternoon of proestrus, soon after estrogen levels peak physiologically and shortly before the estrus-related decline in estrogen, the pattern of hybridization to the estrogen receptor probe was more heterogeneous, as compared to the OVX condition (Fig. $3 B$ ). While there were a few darkly stained neurons present, the hybridization signal was markedly reduced in the majority of neurons in this group. Plasma estrogen levels for this group were on average $30 \mathrm{pg} / \mathrm{ml}$, consistent with expected estrogen levels on the afternoon of proestrus (Butcher et al., 1974). Hybridization to estrogen receptor $m$ RNA also appeared markedly reduced in OVX animals, $52 \mathrm{hr}$ after a single dose of estrogen (Fig. 3C). While some neurons strongly hybridized the probe, in most instances the hybridization signal in DRG of estrogen-replaced OVX animals at $52 \mathrm{hr}$ was markedly reduced or virtually absent, although this effect was variable at $4 \mathrm{hr}$ after estrogen treatment (data not shown). Plasma estrogen levels at $4 \mathrm{hr}$ after a single injection of estrogen (Fig. 4) were high, resembling levels typically seen on the morning of proestrus, while at $52 \mathrm{hr}$, estrogen levels had fallen almost threefold. It should 


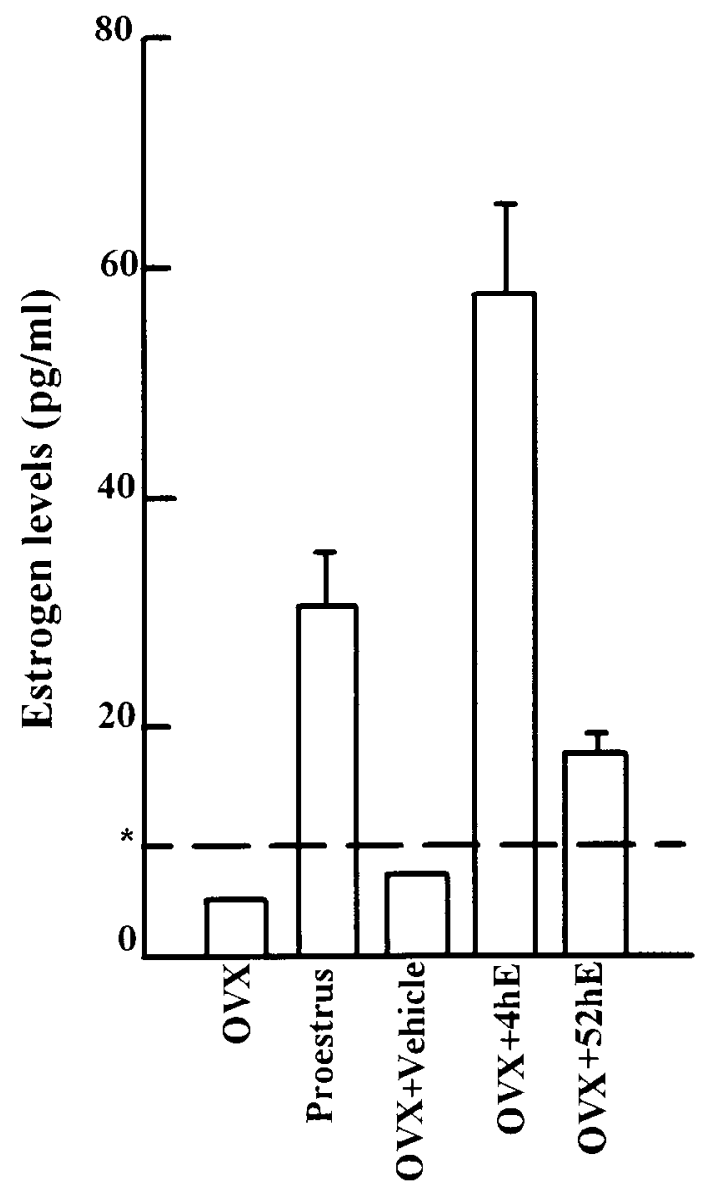

Figure 4. Plasma estrogen levels. Plasma estrogen levels were determined in OVX, proestrus, and estrogen-replaced OVX animals using an iodinated estradiol antibody kit. Bar graph represents the mean $( \pm$ SEM) estrogen levels detected, consisting of three animals from each hormonal condition. The level of estrogen in untreated $(O V X)$ and vehicle-treated $\mathrm{OVX}(O V X+V e h i c l e)$ animals was undetectable by this assay (below $8 \mathrm{pg} / \mathrm{ml}$ ) while the mean estrogen levels of intact (Proestrus) animals agrees closely with those reported the afternoon of proestrus (Butcher et al., 1974). OVX animals given a single injection of EB (10 $\mu \mathrm{g})$ had high levels of estrogen $4 \mathrm{hr}$ later $(O V X+4 h E)$, comparable to those seen on the morning of proestrus, which declined threefold when measured $52 \mathrm{hr}(O V X+52 h E)$ after the injection. Asterisk indicates 8 $\mathrm{pg} / \mathrm{ml}$, the lower limit of the sensitivity of the assay.

be noted that in the intact animal, estrogen titers that are very low at metestrus, rise gradually to peak on the morning of proestrus (2-2.5 d later) and fall shortly thereafter. Hence, the decrease in estrogen receptor $m$ RNA hybridization during proestrus and at $52 \mathrm{hr}$ after estrogen treatment suggests, as has been shown in the brain (Lauber et al., 1990; Simerly and Young, 1991; Shughrue et al., 1992), that prolonged exposure to estrogen downregulates the expression of its own receptor mRNA in sensory neurons.

\section{Ovarian hormones upregulate $N G F$ receptor $m R N A s$}

We also analyzed the expression of the two NGF receptor mRNAs $\mathrm{p} 75^{\mathrm{NGFR}}$ and $t r k A$ in OVX, proestrus, and estrogen-replaced OVX animals, by in situ hybridization histochemistry, using oligodeoxynucleotide probes, and by Northern blot analysis, using cDNA probes.

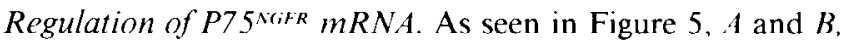
DRG neurons, hybridized with the oligonucleotide probe for p $75^{\mathrm{NG} \text { iFR }}$ mRNA, exhibited some level of expression for this receptor mRNA irrespective of the hormonal status of the animal. While both large and small neurons were equally likely to express p75 $5^{\mathrm{NGR}}$ mRNA, there was a marked difference in the pattern of hybridization to the $\mathrm{p} 75^{\mathrm{NG} \text { FR }}$ probe, depending upon the estrogen status of the animal. While some DRG neurons from OVX animals did hybridize the p $75^{\mathrm{NG} F \mathrm{FR}}$ probe, Figure 5.4 shows that there were many neurons present that did not detectably express this mRNA. The proportion of DRG neurons, from OVX animals, expressing p $75^{\mathrm{N}(\mathrm{iFR}} \mathrm{mRNA}$ varied from one experimental run to another; hence, their numbers were not quantified, although these ranged approximately from one-fourth to one-half of the neurons present in a section. Among those neurons that did express the mRNA, a few were darkly stained but the majority had a pale hybridization product, indicating that the expression of hybrids in these neurons was significantly low. This pattern of hybridization was in striking contrast to the one seen in DRG neurons of the proestrus animal probed for $\mathrm{p} 75^{\mathrm{NGFR}} \mathrm{mRNA}$. In these ganglia, virtually every neuron appeared to express the mRNA, and the homogeneous dark blue-black hybridization product (Fig. $5 B$ ) indicated that the expression of this mRNA within a given neuron was much higher on average in proestrus than OVX animals.

Northern blot analysis (Fig. 6A) of total RNA from OVX and proestrus DRGs confirmed the differences observed in the in situ hybridization analysis. Optical density measurements of the p75 NGFR transcript (normalized to $18 \mathrm{~S}$ ribosomal RNA) indicated a $62 \%(p<0.05)$ increase in $\mathrm{p} 75^{\mathrm{N} \text { NiFR }} \mathrm{mRNA}$ during proestrus, as compared to OVX controls. The Northern analysis confirmed the direction of proestrus induced changes seen by in situ hybridization analysis, although the colorimetric reaction appears to exaggerate the difference in p $75^{\text {NiFR }} \mathrm{mRNA}$ expression. However, the alkaline phosphatase reaction is not linear and therefore unsuitable for quantitation, unlike the Northern blot analysis. Our results thus indicate that the hormonal conditions cxisting at procstrus thus appcarcd to upregulate NGF receptor mRNA, in contrast to the downregulation of estrogen receptor mRNA.

Regulation of trkA $m R N A$. Hybridization with the oligonucleotide probe for trkA mRNA in DRG neurons revealed an expression pattern similar to that of $\mathrm{p} 75^{\mathrm{NGFR}} \mathrm{mRNA}$, that is, a reduced level of expression in OVX animals, as compared to proestrus. In the OVX animal (Fig. $5 C$ ), a few darkly labeled neurons were generally found scattered in the periphery and center of the ganglion. The majority of neurons, however, were pale colored, indicative of significantly lowered levels of mRNA expression. However, the pattern of hybridization was considerably altered during proestrus, where almost every neuron in the ganglion appeared to hybridize strongly with the $\operatorname{trk} A$ probe, as shown by the dark blue-black staining of the DRG neurons of Figure $5 D$. Both the number of hybridizing neurons and the intensity of the hybridization signal appeared greater in the proestrus condition.

Northern blot analysis of $\operatorname{trk} A$ RNA obtained from DRGs of proestrus and OVX animals confirmed the observed differences in the pattern of hybridization seen by in situ hybridization (Fig. $6 B$ ). The levels of $t r k A$ mRNA, measured densitometrically and normalized to an internal control ( $18 \mathrm{~S}$ ribosomal RNA), were, on average, threefold (285\%) greater during proestrus as compared to the OVX condition. Thus, both NGF receptor mRNAs 

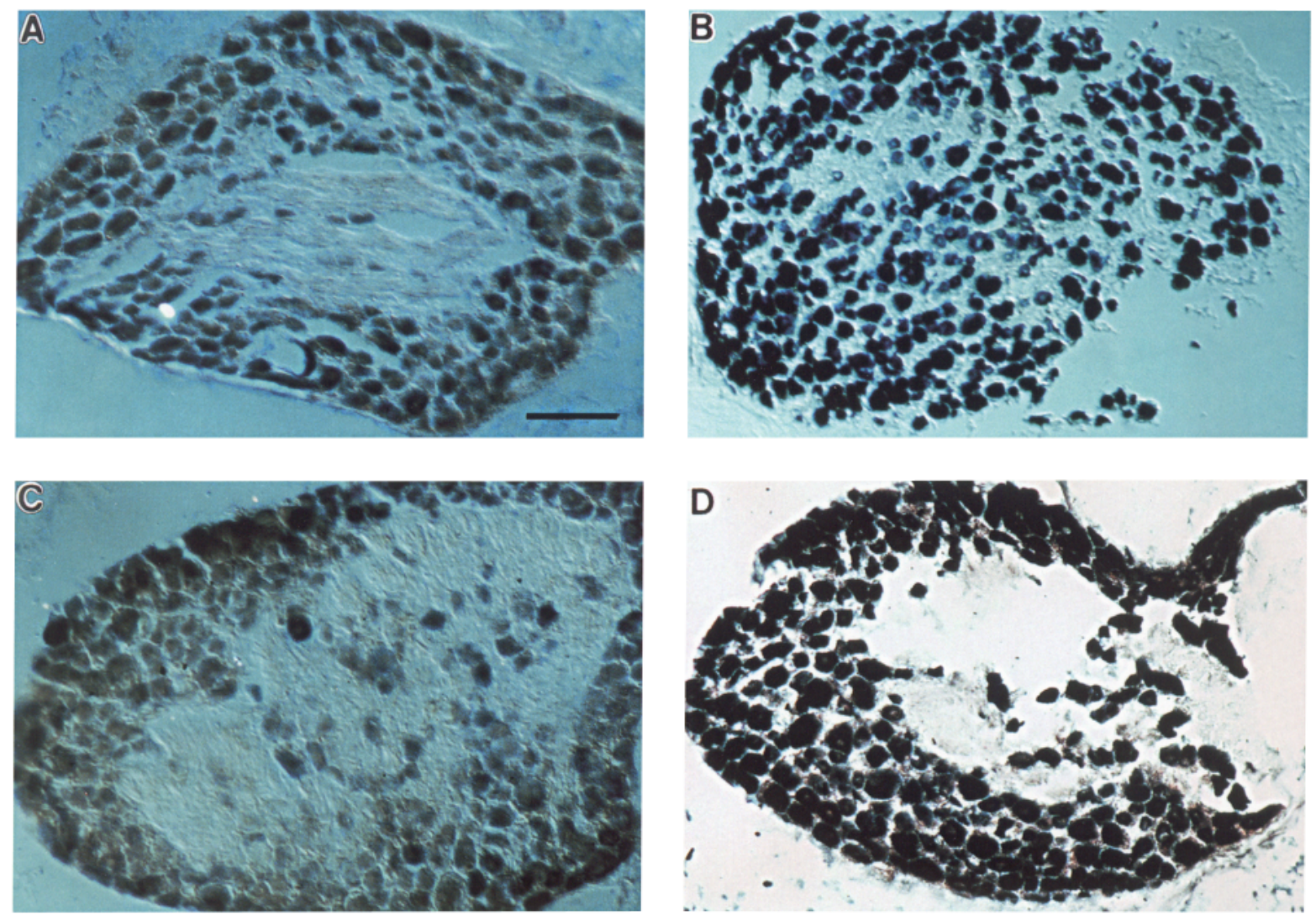

Figure 5. $A-D$, NGF receptor mRNAs in DRG neurons. Twenty micrometer cryostat sections through DRG of OVX and intact females were hybridized to digoxigenin-labeled oligonucleotide probes for the p $75^{\text {NGFR }}$ (46 bases) and $\operatorname{trkA}$ ( 60 bases) mRNA. While NGF receptor mRNAs were expressed in both hormonal conditions, the extent of hybridization to p75 $\operatorname{OVX}(A$ and $C)$ animals as compared to intact animals during proestrus $(B$ and $D)$. $(A-C$ were photographed with Nomarski optics; $D$, bright-field photograph.) Scale bar, $100 \mu \mathrm{m}$.

appeared to be increased in the proestrus condition, when compared to the OVX animals, $\operatorname{trk} A$ more so than $\mathrm{p} 75^{\mathrm{NGFR}}$.

\section{Estrogen regulation of $p 75^{\text {NGFR }}$ and trkA $m R N A$}

To assess directly the effect of estrogen on NGF receptor mRNA, we then compared OVX animals with those replaced with a single dose of estrogen (estradiol benzoate, EB) and killed 4 or $52 \mathrm{hr}$ later. Plasma estrogen assays indicated that, while OVX animals had undetectable levels of estrogen, $4 \mathrm{hr}$ after a single dose of estrogen, estrogen titers rose to $58 \mathrm{pg} / \mathrm{ml}$, comparable to levels seen in the morning of proestrus. Fifty-two hours after a single injection of estrogen, estrogen levels had fallen to 17 $\mathrm{pg} / \mathrm{ml}$ (Fig. 4).

Northern blot analysis of p75 tained from animals replaced with estrogen indicated that estrogen transiently downregulated this receptor mRNA $(p<0.05$; Fig. 7A). Levels of p $75^{\text {NGFR }}$ measured densitometrically (normalized to $18 \mathrm{~S}$ ribosomal RNA) were reduced by half, $4 \mathrm{hr}$ after a single dose of EB and were no different in OVX animals killed $52 \mathrm{hr}$ after a single injection of estrogen, as compared to vehicletreated controls.

However, in the case of trkA (Fig. $7 B$ ), in contrast, densitometric measurements of this transcript in Northern blot analysis indicated that estrogen treatment resulted in a twofold increase in mRNA expression of this NGF receptor $4 \mathrm{hr}$ after a single injection of estrogen $(p<0.01)$ and a threefold increase in $t r k A$ mRNA in OVX animals exposed to $52 \mathrm{hr}$ of estrogen, as com- pared to vehicle treated controls $(p<0.01)$. The levels of $t r k A$ mRNA observed in the OVX $+4 \mathrm{hrE}$ group was not significantly different from the OVX $+52 \mathrm{hrE}$ group, indicating an early and prolonged upregulation of $t r k A$ mRNA by estrogen. Estrogen regulation of $t r k A$ mRNA was also detected by in situ hybridization analyses, using a digoxigenin-labeled oligonucleotide probe for $t r k A$. Hybridization patterns of the $t r k A$ probe, in situ (Fig. 8A,B), closely paralleled Northern analyses of the $t r k A$ transcript (Fig. $7 B$ ), with respect to estrogen treatment. In general, the extent of hybridization of the trkA probe in DRG obtained from vehicle-treated controls appeared low. While there were a few darkly staining neurons, the majority of neurons were either unstained or had a pale blue color, indicating an overall low level of hybridization product in DRG neurons within this group (Fig. 8A). In contrast, hybridization product was seen in virtually every neuron of DRG obtained from OVX animals exposed to estrogen for $52 \mathrm{hr}$ (Fig. $8 B$ ), with many darkly staining neurons present throughout the ganglion. The extent of hybridization to the trk4 probe in DRG from OVX animals, $4 \mathrm{hr}$ after estrogen treatment (data not shown), appeared intermediate to those seen in the OVX and OVX + $52 \mathrm{hrE}$ groups. p $75^{\mathrm{NGFR}} \mathrm{mRNA}$ regulation by estrogen was not amenable to in situ hybridization analyses given that the already low hybridization to the $\mathrm{p} 75^{\mathrm{NGFR}}$ probe in DRG neurons of untreated OVX animals (example shown in Fig. 5A) would be further decreased in DRG neurons of estrogen-treated OVX animals (as indicated by Northern blot analyses), requiring de- 
A
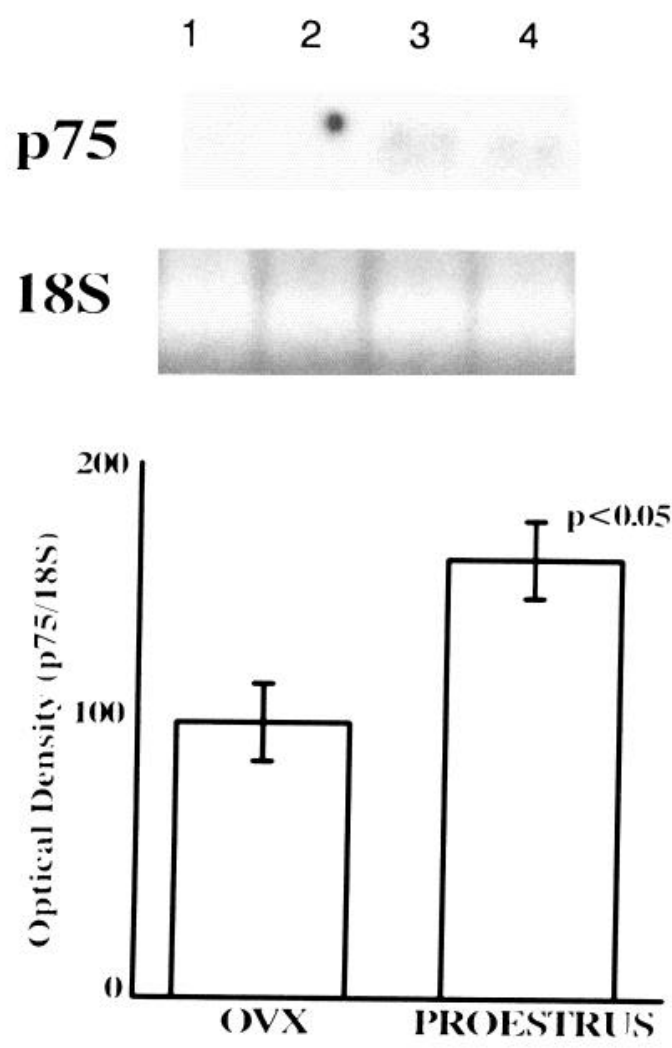

B
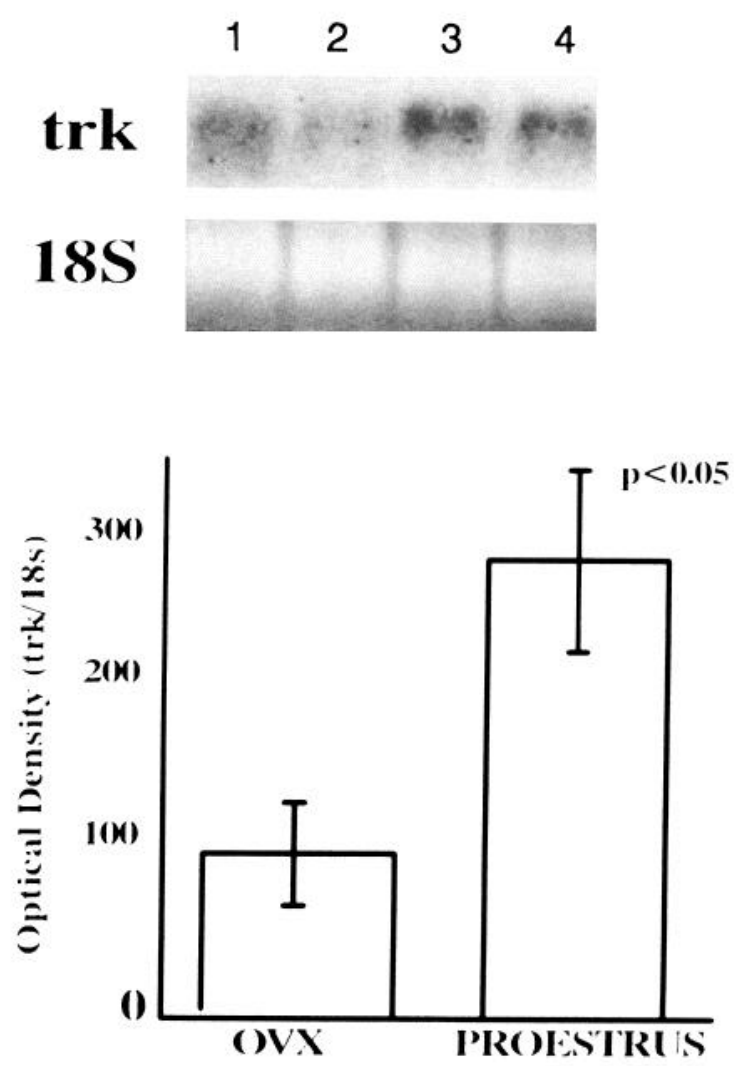

Figure 6. Northern blot analysis of DRG RNA. Total RNA, obtained from DRG of OVX (lanes 1 and 2) and proestrus (lanes 3 and 4 ) females, loaded $15 \mu \mathrm{g}$ per lane, was hybridized to random-primed, ${ }^{32} \mathrm{P}$-labeled cDNA probes for the NGF receptors. $A$, p75 $5^{\mathrm{NGFR}}$ was probed by hybridization with a $2 \mathrm{~kb}$ cDNA probe corresponding to the extracellular domain of the p75 NGFR gene (p5b; Buck et al., 1988). B, trkA mRNA was identified by hybridization with a $450 \mathrm{bp} t r k A$-specific cDNA probe corresponding to the extracellular and transmembrane domains of the $t r k A$ gene (pDM 97 ; Martin-Zanca et al., 1989; gift of L. F. Parada). To quantify group differences, optical density of the NGF receptor transcripts was normalized to $18 \mathrm{~S}$ ribosomal RNA, to control for variations in the amount of total RNA loaded onto the gel. Bar graph represents mean ( \pm SEM) of three animals from each hormonal condition. Statistically significant $(p<0.05)$ differences as compared to the untreated OVX group are indicated.

tection of differences beyond the sensitivity of most, including this, colorimetric assay.

\section{Discussion}

The present data indicate that adult female rat sensory neurons are estrogen targets, in vivo, and that estrogen treatment differentially modulates the expression of estrogen and NGF receptor mRNAs. These findings suggest that estrogen may regulate peripheral neuronal sensitivity to both estrogen and the neurotrophins. Our data indicate that estrogen receptor mRNA and specific, competable, nuclear estrogen-binding sites (receptors) are present in adult sensory ganglia. Moreover, the estrogen status of the animal appears to regulate reciprocally the expression of estrogen receptor mRNA and the mRNAs for the NGF receptors $\mathrm{p} 75^{\mathrm{NGFR}}$ and $t r k A$ in adult sensory neurons. While estrogen receptor mRNA is downregulated and NGF receptors upregulated during proestrus, estrogen replacement in OVX animals, in contrast, appears to downregulate mRNA for the estrogen receptor and the pan-neurotrophin receptor $\mathrm{p} 75^{\mathrm{NGFR}}$, while upregulating $t r k A$ mRNA. The present findings are consistent with our hypothesis that estrogen sensitivity may be a general feature of the neural targets of neurotrophins, in this case NGF, and that some of estrogen's action on neural tissue may result via estrogen-induced transcriptional regulation of the neurotrophin receptors. The potential universality of these interactions is suggested, moreover, by preliminary findings that $\mathrm{PC} 12$ cells, another prototypical target of NGF, have estrogen-binding sites, and in this cell type as well, estrogen appears to regulate differentially both p $75^{\mathrm{NGFR}}$ and $t r k A$ mRNA (F. Sohrabji, L. A. Greene, R. C. Miranda, and C. D. Toran-Allerand, unpublished observations).

Although estrogen receptors have not been previously reported in adult sensory neurons, the widespread expression of estrogen receptor mRNA observed in DRG neurons and the presence of nuclear estrogen-binding sites argue that these neurons are estrogen targets. While the levels of estrogen-binding sites in sensory ganglia appear low, they are within the range reported for estrogen targets in the adult brain (Friedman et al., 1983). It should be noted, however, that the estimates of estrogen-binding sites reported here may underestimate the proportion of estrogen receptors in DRG neurons. First, binding sites were normalized to total DNA content of the ganglia, while the in situ hybridization analysis indicates that estrogen receptor mRNA was predominantly expressed only in neurons and not support cells of the DRG. Additionally, binding assays that used Dulbecco's MEM (see Materials and Methods) were not phenol red free, and a contaminant found intermittently in phenol red dye lots is reportedly estrogenic (Berthois et al., 1986; Bindal and Katzenellenbogen, 1988), which may contribute to underestimates of actual binding sites. In fact, preliminary assays using phenol red-free media suggest that estrogen binding estimates in DRG are substantially higher. In addition to the 
A p75 N(iF

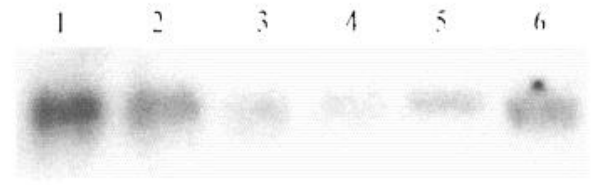

$18 \mathrm{~S}$
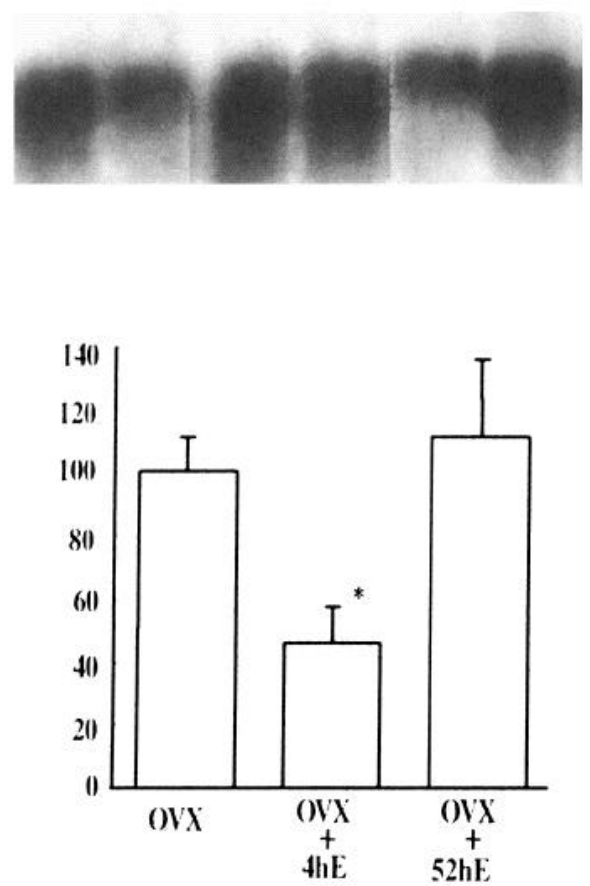

B

trki

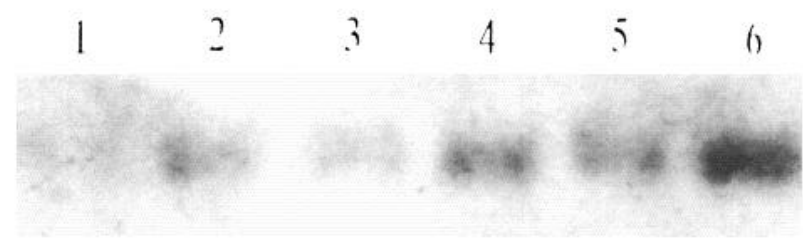

$18 \mathrm{~S}$

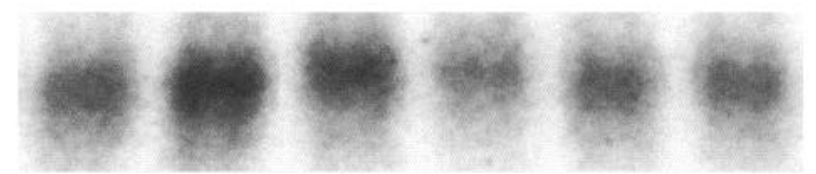

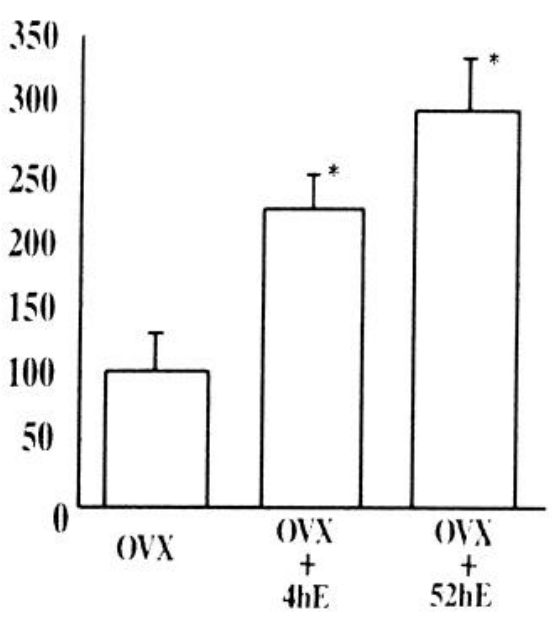

Figure 7. Northern blot analyses of estrogen regulation of NGF receptor mRNAs. Total RNA, loaded $25 \mu \mathrm{g}$ per lane, was obtained from DRG of vehicle-treated OVX animals (lanes 1 and 2) and OVX animals killed $4 \mathrm{hr}$ (lanes 3 and 4 ) and $52 \mathrm{hr}$ (lanes 5 and 6 ) after a single injection of EB. Nylon filters were hybridized with random-primed, ${ }^{32} \mathrm{P}$-labeled cDNA probes for either a $2 \mathrm{~kb}$ cDNA probe corresponding to the extracellular

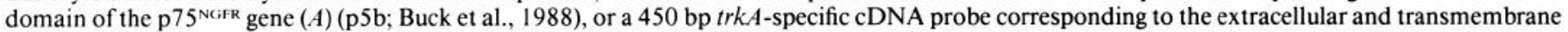
domains of the trkA gene (B) (pDM97; Martin-Zanca et al., 1989; gift of L. F. Parada). To quantify group differences, optical density of the NGF receptor transcripts was normalized to $18 \mathrm{~S}$ ribosomal RNA, to control for variations in the amount of total RNA loaded onto the gel. Bar graph represents mean $( \pm$ SEM) of five animals from each group. Asterisks indicate statistically significant $(p<0.05)$ differences as compared to the vehicle-treated OVX group.

binding assays, the effect of estrogen on NGF receptor mRNA expression further supports the concept of the existence of functional estrogen receptors in DRG neurons. Our present data are also consistent with reports that developing DRG and other peripheral neurons are responsive to estrogen. For example, neonatal exposure to estrogen reportedly increases both neuron and synapse number in the SCG (Wright and Smollen, 1983a). More recently, it has been shown that those lumbosacral spine motoneurons that innervate the bulbocavernosus muscle [spinal nucleus of the bulbocavernosus (SNB)], if exposed to early estrogen treatment, initiate elaborate dendrite arborizations (D. Sengelaub, personal communication). Since neither estrogen receptors (binding sites) (Pfaff and Keiner, 1973; Sar and Stumpf, 1977; Breedlove and Arnold, 1980) nor mRNA (Simerly et al., 1990) have been found in adult SNB motoneurons, this dendrite growth may well result indirectly from the action of estrogen on those neurons and processes afferent to the SNB, namely, the L5, L6, and S1 DRG neurons.

In the present study, the expression of estrogen receptor mRNA was markedly reduced in DRG neurons of the proestrus animal, as well as OVX animals $52 \mathrm{hr}$ after exposure to estrogen, as compared to ovariectomized controls. Both the direction and relative time course of estrogen-dependent downregulation of estrogen receptor mRNA in sensory neurons are similar to that observed in the adult brain (Simerly and Young, 1991; Lauber et al., 1992) and extraneural targets of estrogen such as the uterus (Shupnik et al., 1989). In the case of proestrus animals, furthermore, downregulation of estrogen receptor mRNA in sensory neurons is similar to that observed in the intact adult brain compared to the OVX condition. For example, in established targets of estrogen such as the medial preoptic area and the ventromedial and arcuate nuclei of the hypothalamus, ovariectomy reportedly increases the level of estrogen receptor mRNA, when compared to any stage in the estrus cycle of the intact female (Shughrue et al., 1992). Similarly, OVX animals with hormone replacement also show marked downregulation of estrogen receptor mRNA in the ventrolateral aspect of the ventromedial nucleus and in the arcuate nucleus of the hypothalamus $18 \mathrm{hr}$ and later, although this effect is not apparent at 4 $\mathrm{hr}$ following estrogen treatment (Lauber et al., 1992). Exposure to estrogen in the form of an implanted silastic capsule also depressed estrogen mRNA levels in these regions, when measured 24 and $72 \mathrm{hr}$ later (Simerly and Young, 1991). In the present study, while estrogen consistently downregulated its receptor mRNA at $52 \mathrm{hr}$, the effects of estrogen at $4 \mathrm{hr}$ were more variable, being downregulated in some cases, and unchanged 
Figure 8. In situ hybridization analyses of trkA mRNA. DRG sections (20 $\mu \mathrm{m}$ thick), obtained from vehicle- and estrogen-treated OVX animals, were hybridized with a digoxigenin-labeled oligonucleotide probe for $\operatorname{trk} A$ mRNA. The extent of hybridization to the trkA probe was low in sensory neurons of vehicle-treated OVX animals $(A)$, but increased dramatically in OVX animals exposed to estrogen for $52 \mathrm{hr}(B)$. Photographed with Nomarski optics. Scale bar, $100 \mu \mathrm{m}$.
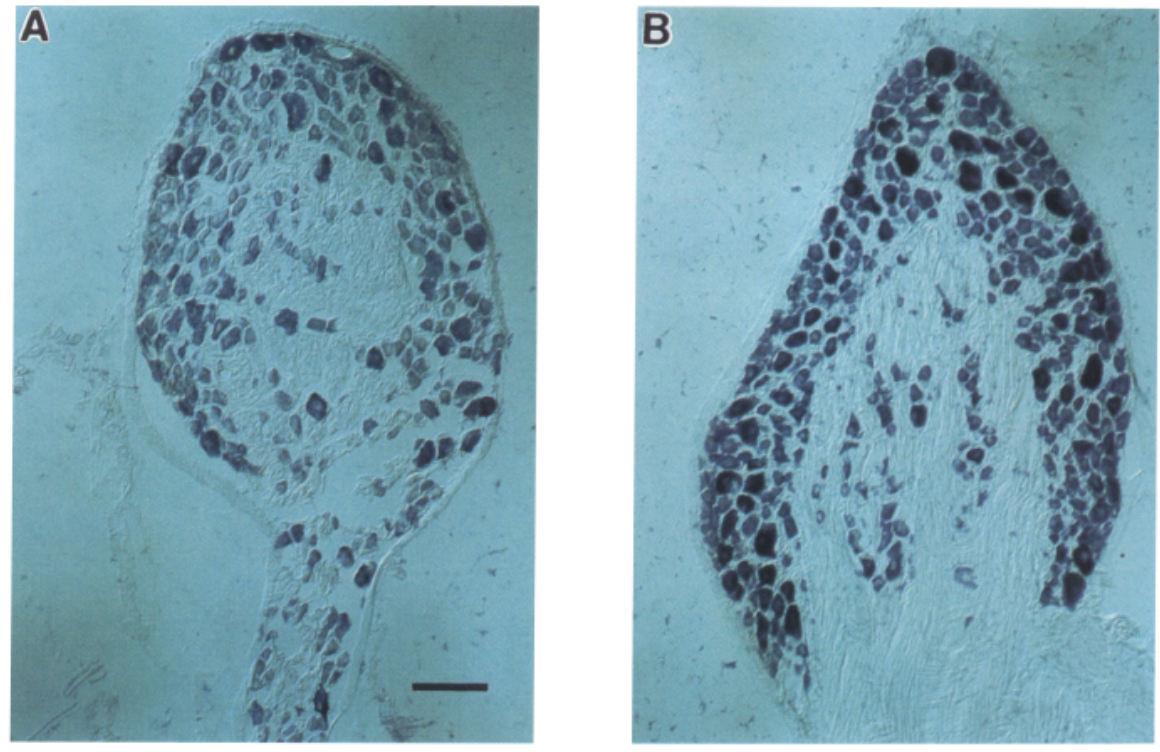

from controls (OVX) in other instances (data not shown). In general, though, it appears that the direction and time course of estrogen receptor mRNA regulation in DRG neurons are similar to that seen in the central neural targets of estrogen.

While the hormonal conditions during proestrus and estrogen replacement of OVX animals both downregulate estrogen receptor mRNA, they appear to have different effects on the two NGF receptor mRNAs present in DRG neurons. Both NGF receptors are present in DRG neurons: the $\mathrm{p} 75^{\mathrm{NGFR}}$ protein, the first cloned NGF receptor (Chao et al., 1986; Johnson et al., 1986; Radeke et al., 1987), and trkA (Martin-Zanca et al., 1990). Compared to OVX animals, expression of $\operatorname{trk} A$ mRNA was enhanced comparably in both the proestrus animal as well as the estrogen-replaced OVX animals. trkA mRNA expression was significantly higher than controls $4 \mathrm{hr}$ after estrogen treatment and remained upregulated $52 \mathrm{hr}$ after estrogen treatment. There appeared to be no statistically significant increment in $\operatorname{trkA}$ mRNA expression between 4 and $52 \mathrm{hr}$ of estrogen treatment, although at the present time we cannot determine whether estrogen acts by continuous stimulation of the $\operatorname{trk} A$ gene or by increasing the half-life of its transcript. While $\operatorname{trk} A$ mRNA levels remained equally high at both time points, estrogen titers at 52 $\mathrm{hr}$ postinjection were threefold lower than at $4 \mathrm{hr}$ postinjection. Hence, unlike p75 NGFR mRNA, which fell at $4 \mathrm{hr}$ of estrogen treatment and returned to basal levels at $52 \mathrm{hr}, \operatorname{trkA}$ mRNA levels appear not to have fallen in response to decreasing availability of estrogen. However, since estrogen levels did not fall to basal (OVX) levels by $52 \mathrm{hr}$ we can only speculate that even the low levels of estrogen present were capable of stimulating this gene. To test accurately whether $\operatorname{trkA}$ mRNA levels fall if estrogen is subsequently removed would be more feasible in a tissue culture system where exposure and deprivation of a ligand are more feasible.

While trkA mRNA was upregulated in both the proestrus and estrogen replacement condition, $p 75^{\mathrm{NGFR}}$ mRNA, on the other hand, which appeared enhanced during proestrus, was downregulated $50 \%$ following estrogen treatment, as compared to OVX controls. The most obvious explanation for the discrepancy in p $75^{\text {NGFR }}$ mRNA regulation between the two paradigms lies in the fact that, although estrogen titers are very high at proestrus, it is not the only gonadal hormone present at this time. In addition to estrogen, there are high levels of testosterone, prolactin, and follicle-stimulating hormone present during the afternoon of proestrus (Brown-Grant et al., 1970; Neill, 1972; Butcher et al., 1974), which may influence transcription of NGF receptors. It may prove to be the case that estrogen interactions with other hormones present at proestrus may result in markedly different outcomes from that of estrogen acting alone, as in the estrogen-replaced OVX animals. Thus, the changes in NGF receptor mRNA during proestrus must represent a sum total of several hormones exerting diverse control of the same gene, although the similarity on the direction and amount of trkA mRNA regulation in both paradigms (OVX/ proestrus and estrogen-replaced $\mathrm{OVX}$ ) suggests that $\operatorname{trk} A \mathrm{mRNA}$ upregulation during proestrus may be due specifically to the high titers of estrogen present at this time.

Although estrogen appears to have differential effects on the two components of the NGF receptor, its actions appear to be consistent with those reported for other members of the steroidthyroid hormone receptor superfamily of transcription factors. For example, replacing testosterone, a related gonadal hormone, downregulates p75 NGFR $\mathrm{mRNA}$ in Sertoli cells of the adult testis, an androgen target (Persson et al., 1990). In the brain, longterm (16-30 d) exposure to a silastic implant of estrogen is reported to decrease p $75^{\mathrm{NGFR}} \mathrm{mRNA}$ in the hippocampus and septum (Gibbs and Pfaff, 1992). Retinoic acid, another member of this superfamily of DNA-binding proteins, has been shown to increase ${ }^{125} \mathrm{I}-\mathrm{NGF}$ binding in Lan-1 neuroblastoma cells (Haskell et al., 1991) and in developing chick sympathetic neurons (Rodriguez-Tebar et al., 1991) and to increase trkA mRNA in neuroblastoma cells (D. R. Kaplan, personal communication). In fact, our own preliminary data from PC12 cells indicate that estrogen upregulates $\operatorname{trk} A$ mRNA and downregulates p75 $5^{\text {NGFR }}$ mRNA (Sohrabji, Greene, Miranda, and Toran-Allerand, unpublished observations), to a similar extent as in the DRG.

At the present time, we can only speculate on the biological and functional significance of differential regulation of NGF receptor mRNAs by estrogen, since the precise role of each receptor is not clearly known. While $\mathrm{p} 75^{\mathrm{NGFR}}$ and $\operatorname{trk} A$ individually bind NGF with low affinity, together they demonstrate a 
high-affinity binding characteristic (Hempstead et al., 1991). Some evidence suggests, however, that cellular requirements for the two NGF receptors may differ. In a mutant form (nnr) of PC1 2 cells, which does not respond to NGF with neurite elongation (Greene et al., 1986), p75 $5^{\mathrm{NGFR}}$ is present at the usual levels but trkA mKNA is severely depleted (Loeb et al., 1991). Transfecting these mutants with an expression vector encoding $t r k A$ cDNA rcinstated the capacity for NGF-induced neurite outgrowth (Loeb et al., 1991), suggesting that $\operatorname{trk} A$ is necessary for neurotrophin-mediated signal transduction. Hence, if $\operatorname{trk} A$ is the signal transducing arm of the NGF receptor, estrogen, by increasing $t r k A$ mRNA in sensory ganglia, may be in a position to alter neuronal responsivity to NGF, by altering the ratio of p $75^{\text {NGirk }}$ and $t r k A$, and consequently, the formation of the hypothetical NGF receptor complex as recently suggested by Chao and colleagues (Battleman et al., 1993). In addition, it is interesting to note that preliminary evidence from transfected NIH$3 \mathrm{~T} 3$ cells indicates that overexpression of $\mathrm{p} 75^{\mathrm{NGFR}}$ inhibits autophosphorylation of $t r k A$ (D. R. Kaplan, personal communication). It may be that estrogen, by increasing $t r k A$ mRNA while decreasing $\mathrm{p} 75^{\mathrm{NGFR}} \mathrm{mRNA}$, may modulate ligand-independent signal transduction by receptor tyrosine kinases. Although the present study focused on estrogen regulation of neurotrophin receptors that bind NGF, DRG neurons also express trkB and $t r k C$, which bind other members of the neurotrophin family of growth factors. Localization of estrogen receptors in neurotrophin target neurons both in the DRG and CNS suggests that estrogen may be in a position to regulate mRNA expression of other tyrosine kinase receptors as well.

Estrogen replacement may downregulate p $75^{\mathrm{NGFR}} \mathrm{mRNA}$ in neurotrophin targets such as the DRGs and the basal forebrain (Gibbs and Pfaff, 1992) of the uninjured adult, but its actions on this gene may be different during periods of critical neurotrophin requirement such as development or following injury. For example, early neonatal exposure to estrogen appears to increase high-affinity NGF receptor binding, as determined by ${ }^{125}$ I-NGF binding in DRG neurons (Wright et al., 1988), suggesting that estrogen may increase both $\operatorname{trk} A$ and $\mathrm{p} 75^{\mathrm{NG} T \mathrm{rR}}$ transcriptionally or posttranscriptionally. Moreover in the adult brain, where estrogen downregulates $p 75^{\mathrm{NGFR}} \mathrm{mRNA}$ in the intact basal forebrain, it appears not to augment the loss of $p 75^{\mathrm{NGFR}}$ mRNA, following fimbria-fornix lesions (Gibbs and Pfaff, 1992). Furthermore, estrogen treatment has been reported to have a beneficial effect on peripheral nerve regeneration (Bajusz, 1959), consistent with the hypothesis that estrogen, via interactions with growth factors known to ameliorate injury in the adult PNS, such as the neurotrophins, may have a protective role following neural injury.

The modulation of neurotrophin receptor mRNAs by gonadal hormones, particularly estrogen, in adult peripheral neural targets of NGF suggests a critical role for these steroids in mediating NGF-dependent regulation of neuronal survival, plasticity, and repair. Evidence from this laboratory indicates that estrogen receptor mRNA or protein colocalizes with $t r k A$ and $t r k B$ mRNA as well as $\mathrm{p} 75^{\mathrm{NGFR}} \mathrm{mRNA}$ or protein in neurotrophin targets of the developing forebrain (Toran-Allerand et al., 1992a; Miranda et al., 1993), suggesting the potential for estrogen regulation of NGF receptors in the CNS, as well as the potential for estrogen regulation of other members of the tyrosine kinase family of neurotrophin receptors. Moreover, since $\mathrm{p} 75^{\mathrm{NGFR}}$ binds BDNF and NT-3 as well as NGF, gonadal hormones may also alter responsivity of target neurons to other members of the neuro- trophin family. Steroid/neurotrophin interactions suggest a mechanism by which transcription factors such as the estrogen receptor, via actions on other transcription-regulating factors, may exert wide influences on the nervous system.

\section{References}

Bajusz E (1959) Effect of hormones upon regression of muscle atrophy of nervous origin. Endocrinology 64:262-269.

Barde YA, Edgar D, Thoenen H (1980) Sensory neurons in culture. Changing requirements for survival factors during embryonic development. Proc Natl Acad Sci USA 77:1199-1203.

Battleman DS, Geller AI, Chao MV (1993) HSV-1 vector-mediated gene transfer of the human nerve growth factor receptor $\mathrm{p} 75^{\mathrm{hNCFR}}$ defines high-affinity NGF binding. J Neurosci 13:941-951

Beato M (1989) Gene regulation by steroid hormones. Cell 56:335344.

Berthois Y, Katzenellenbogen JA, Katzenellenbogen BS (1986) Phenol red in tissue culture is a weak estrogen: implications concerning the study of estrogen-responsive cells in culture. Proc Natl Acad Sci USA 83:2496-2500.

Bindal RD, Katzenellenbogen JA (1988) Bis(4-hydroxyphenyl)'2(phenoxysulfonyl)phenyl-methane: isolation and structure elucidation of a novel estrogen from commercial preparations of phenol red (phenolsulfonphthalein). J Med Chem 31:1978-1983.

Breedlove SM, Arnold AP (1980) Hormone accumulation in a sexually dimorphic motor nucleus of the rat spinal cord. Science 210:564566.

Brown-Grant K, Exley D, Naftolin F (1970) Peripheral plasma oestradiol and luteinizing hormone concentration during the oestrus cycle of the rat. J Endocrinol 48:261-295.

Buck CR, Martinez HJ, Chao MV, Black IB (1988) Differential expression of nerve growth factor receptor gene in multiple brain areas. Dev Brain Res 44:259-268.

Butcher RL, Collins WE, Fugo NW (1974) Plasma concentrations of LH, FSH, prolactin, progesterone and estradiol-17 $\beta$ throughout the 4 day estrous cycle of the rat. Endocrinology 94:1704-1708.

Cesarone C, Bolognesi C, Santi L (1979) Improved microfluorometric DNA determination in biological material using 33258 Huechst. Anal Biochem 102:188-197.

Chao MV, Bothwell MA, Ross AH, Koprowski H, Lanahan AA, Buck CK, Sehgal A (1986) Gene transfer and molecular cloning of the human NGF receptor. Science 232:518-521.

Chomczynski P, Sacchi N (1987) Single step method of RNA isolation by acid guanidinium thiocyanate-phenol-chloroform extraction. Anal Biochem 162:156-159.

Csillick B (1987) Transganglionic regulation of the primary sensory neuron. Acta Physiol Acad Sci Hung 69:355-361.

DeKloet ER, Voorhuis DAM, Boschma Y, Elands J (1986) Estradiol modulates density of putative 'oxy tocin receptors' in discrete rat brain regions. Neuroendocrinology 44:415-421.

Dohanich GP, Witcher JA, Weaver DR, Clemens LG (1982) Alterations of muscarinic binding in specific brain areas following estrogen treatment. Brain Res 241:347-350.

Eckenstein F (1988) Transient expression of NGF-receptor-like immunoreactivity in postnatal rat brain and spinal cord. Brain Res 446: 149-154.

Eichler ME, Rich KM (1989) Death of sensory ganglion neurons after acute withdrawal of nerve growth factor in dissociated cell cultures. Brain Res 482:340-346.

Ernfors P, Hallbrook F, Ebendal T, Shooter EM, Radeke MJ, Misko TP, Persson H (1988) Developmental and regional expression of $\beta$-nerve growth factor receptor mRNA in the chick and rat. Neuron $1: 983-996$.

Evans RM (1988) The steroid and thyroid hormone receptor superfamily. Science 240:889-895.

Frankfurt M, Gould E, Woolley C, McEwen BS (1990) Gonadal steroids modify spine density in the ventromedial hypothalamus neurons: a Golgi study. Neuroendocrinology 51:530-535.

Friedman WJ, McEwen BS, Toran-Allerand CD, Gerlach JL (1983) Perinatal development of hypothalamic and cortical estrogen receptors in mouse brain: methodological aspects. Dev Brain Res 11:1927.

Gibbs R, Pfaff DW (1992) Effects of estrogen and fimbria/fornix tran- 
section on P75NGFR and ChAT expression in the medial septum and diagonal band of Broca. Exp Neurol 116:23-39.

Greene SH, Rydel RE, Conolly JL, Greene LA (1986) PC1 2 cell mutants that possess low- but not high-affinity nerve growth factor receptors neither respond to nor internalize nerve growth factor. J Cell Biol 102:830-843.

Guo IZ, Gorski J (1988) Estogen effects on histone messenger ribonucleic acid levels in the rat uterus. Mol Endocrinol 2:693-700.

Hammer RP, Jacobson CD (1984) Sex difference in dendritic development of the sexually dimorphic nucleus of the preoptic area in the rat. Int J Dev Neurosci 2:77-85.

Haskell BE, Stach RW, Werbach-Perez K, Perez-Polo JR (1987) Effect of retinoic acid on nerve growth factor receptors. Cell Tissue Res 247: $67-73$.

Hempstead BL, Martin-Zanca D, Kaplan DR, Parada LF, Chas MV (1991) High-affinity NGF binding requires the co-expression of the trk proto-oncogene and the low-affinity receptor. Nature 350:678:683.

Johnson D, Lanahan A, Buck CR, Sehgal A, Morgan C, Mercer E, Bothwell M, Chao M (1986) Expression and structure of the human NGF receptor. Cell 47:545-554.

Johnson EM, Gorin PD, Brandies LD, Pearson J (1980) Dorsal root ganglion neurons are destroyed by exposure in utero to maternal antibody to nerve growth factor. Science 210:916-918.

Jones KJ, Chikaraishi DM, Harrington CA, McEwen BS, Pfaff DW (1986) In situ hybridization detection of estradiol-induced changes in ribosomal RNA levels in rat brain. Mol Brain Res 1:145-152.

Kaplan DR, Hempstead BL, Martin-Zanca D, Chao MV, Parada LF (1991a) The trk protooncogene product: a signal transducing receptor for nerve growth factor. Science 252:554-558.

Kaplan DR, Martin-Zanca D, Parada LF (199lb) Tyrosine phosphorylation and tyrosine kinase activity of the trk protooncogene product induced by NGF. Nature 350:158-160.

Klein-Hitpass L, Schorpp M, Wagner U, Ryffel GU (1986) An estrogen-responsive element derived from the 5 ' flanking region of the Xenopus vitellogenin A2 gene functions in transfected human cells. Cell 46:1053-1061.

Koh S. Loy R (1989) Localization and development of nerve growth factor-sensitive rat basal forcbrain ncurons and their efferent projections to hippocampus and neocortex. J Neurosci 9:2999-3018.

Koike S, Sakai M, Maramatsu M (1987) Molecular cloning and characterization of the rat estrogen receptor cDNA. Nucleic Acids Res $15: 2499-2513$.

Lamballe F, Klein R, Barbacid M (1991) trkC, a new member of the family of the trk family of tyrosine protein kinases, is a receptor for neurotrophin-3. Cell 66:967-979.

Lauber AH, Romano GJ, Mobbs CV, Pfaff DW (1990) Estradiol regulation of estrogen receptor messenger ribonucleic acid in rat mediobasal hypothalamus: an in situ hybridization study. J Neuroendocrinol 2:605-612

Lindsay RM (1988) Nerve growth factors (NGF, BDNF) enhance axonal regeneration but are not required for survival of adult sensory neurons. J Ncurosci 8:2394-2405.

Loeb DM, Maragos J, Martin-Zanca D, Chao MV, Parada LF, Greene LA (1991) The trk proto-oncogene rescues NGF responsiveness in Inutant NGF-nonresponsive PC12 cell lines. Cell 66:961-966.

Loy R, Gerlach JL, McEwen BS (1988) Autoradiographic localization of estradiol-binding neurons in the rat hippocampal formation and entorhinal cortex. Brain Res 467:245-251.

Lu B, Buck CR, Dreyfus CF, Black IB (1989) Expression of NGF and NGF receptor mRNAs in the developing brain: evidence for local delivery and action of NGF. Exp Neurol 104:191-199.

Lustig RH, Sudol M, Pfaff DW, Federoff HJ (1991) Estrogenic regulation and sex dimorphism of growth-associated protein $43 \mathrm{kDa}$ (GAP43) messenger RNA in the rat. Mol Brain Res 11:125-132.

MacLusky NJ. McEwen BS (1978) Oestrogen modulates progestin receptor concentrations in some rat brain regions but not in others. Nature 274:276-278

MacLusky NJ, Brown TJ, Jones E, Leranth C, Hochberg RB (1990) Autoradiographic and microchemical methods for quantitation of steroid receptors. In: Methods in neurosciences, Vol 3, Quantitative and qualitative microscopy (Conn PM, ed), pp 1-35. New York: Academic.

Martin-Zanca D, Oskam R, Mitra G, Copeland T, Barbacid M (1989) Molecular and biochemical characterization of the human trk protooncogene. Mol Cell Biol 9:24-33.
Martin-Zanca D, Barbacid M. Parada LF (1990) Expression of the trk proto-oncogene is restricted to the sensory cranial and spinal ganglia of neural crest origin in mouse development. Genes Dev 4:683-694.

Matsumoto A. Arai Y (1981) Neuronal plasticity in the deafferented hypothalamic arcuate nucleus of adult female rats and its enhancement by treatment with estrogen. J Comp Neurol 197:197-206.

Matsumoto A, Murakami S, Arai Y (1988) Neurotrophic effects of estrogen on the neonatal preoptic area grafted into the adult brain. Cell Tissue Res 252:33-37

Melvin JE, Ilamill RW (1986) Gonadal hormone regulation of neurotransmitter synthesizing enzymes in the developing hypogastric ganglion. Brain Res 383:38-46.

Melvin JE, Hamill RW (1989) Androgen-specific critical periods for the organization of the major pelvic ganglion. J Neurosci 9:736-742.

Miranda RC, Toran-Allerand CD (1992) Developmental expression of estrogen receptor mRNA in the rat cerebral cortex: a non-isotopic in situ hybridization histochemistry study. Cereb Cortex 2:1-15.

Miranda RC. Sohrabji F, Toran-Allerand CD (1993) Fstrogen target neurons express mRNAs for the neurotrophins and their receptors during development: a basis for potential interactions of estrogen with the neurotrophins. Mol Cell Neurosci, in press.

Mobley CM, Woo JE, Edwards RH, Riopelle RJ, Longo FM, Wescamp G, Otten U, Valetta JS, Johnston MV (1989) Developmental regulation of nerve growth factor and its receptor in the rat caudateputamen. Neuron 3:655-664.

Neill JD (1972) Comparison of plasma prolactin levels in cannulated and decapitated rats. Endocrinology 90:568-572.

Nishizuka N, Arai Y (1981) Sexual dimorphism in synaptic organization in the amygdala and its dependence on neonatal hormone environment. Brain Res 212:31-38.

Nishizuka N, Arai Y (1982) Synapse formation in response to estrogen in the medial amygdala developing in the eye. Proc Natl Acad Sci USA 79:7024-7026

O'Malley B (1990) The steroid receptor superfamily: more excitement predicted for the future. Mol Endocrinol 4:363-369.

Persson H, Ayer-Le Lievre C, Sodor O, Villar MJ, Metsis M, Olson L, Ritzen M, Hokfelt T (1990) Expression of $\beta$-nerve growth factor mRNA in Scrtoli cclls down-regulated by testosterone. Science 247 704-707.

Pfaff D, Keiner M (1973) Atlas of estradiol concentrating cells in the central nervous system of the female rat. J Comp Neurol 151:121158.

Radeke MJ, Misko TP, Hsu C, Herzenberg LA, Shooter EM (1987) Gene transfer and molecular cloning of the rat nerve growth factor receptor. Nature 325:593-597.

Rich KM, Disch SP, Eichler ME (1989) The influence of regeneration and nerve growth factor on the neuronal cell body reaction to injury. J Neurocytol 18:569-576

Rodriguez-Tebar A, Rohrer H (1991) Retinoic acid induces NGFdependent survival response and high-affinity NGF receptors in immature chick sympathetic neurons. Development 112:813-820.

Romano GJ, Harlan RE, Shivers BD, Howells RD, Pfaff DW (1988) Estrogen increases proenkephalin messenger ribonucleic acid levels in the ventromedial hypothalmus of the rat. Mol Endocrinol 2:13201328

Sar M, Stumpf WE (1977) Androgen concentration in motor neurons of cranial nerves and spinal cord. Science 197:77-79.

Sehgal A, Patil N, Chao MV (1988) A constitutive promoter directs expression of the nerve growth factor receptor gene. Mol Cell Biol $8: 3160-3167$

Shughrue PJ, Refsdal CD, Dorsa DM (1992) Estrogen receptor messenger ribonucleic acid in female rat brain during the estrus cycle: a comparison with ovariectomized females and intact males. Endocrinology 131:381-388.

Shupnik MA, Rosenzweig BA (1991) Identification of an estrogen response element in the rat luteinizing hormone bela gene. DNAestrogen receptor interactions and functional analysis. J Biol Chem 266:17084-17091.

Shupnik MA, Gordon MS, Chin WW (1989) Tissue specific regulation of rat estrogen receptor mRNAs. Mol Endocrinol 3:660-665.

Simerly RB, Young BJ (1991) Regulation of estrogen receptor messenger ribonucleic acid in rat hypothalamus by sex steroid hormones. Mol Endocrinol 5:424-432.

Simerly RB, Chang C, Muramatsu M, Swanson LW (1990) Distribution of androgen and estrogen receptor mRNA containing cells in 
the rat brain: an in silu hybridization study. J Comp Neurol 294:7695.

Soppet D, Escandon E, Marangos J, Middlemas DS, Reid SW, Blair J, Burton LE, Stanton BR, Kaplan DR, Hunter T, Nikolics K, Parada LF (1991) The neurotrophic factors brain-derived neurotrophic factor and neurotrophin-3 are ligands for the $t r k B$ tyrosine kinase receptor. Cell 65:895-903.

Squinto SP, Stitt TN, Aldrich TH, Davis S, Bianco SM, Radriejewski C, Glass DJ, Masiakowski P, Furth ME, Valenzuela DM, DeStefano PS, Yancopoulos GD (1991) irkB encodes a functional receptor for brain derived neurotrophic factor and ncurolrophin-3 but not nerve growth factor. Cell 65:885-893.

Stanley HF, Fink G (1986) Synthesis of specific brain proteins is influenced by testosterone at mRNA lcvel in the neonatal rat. Brain Res 370:223-231.

Stanley HF, Borthwick NM, Fink G (1986) Brain protein changes during development and sexual differentiation in the rat. Brain Res 370:215-222.

Tanjuchi M, Schweitzer JB, Johnson EM (1986) Nerve growth factor receptors in the tat brain. Proc Natl Acad Sci USA 83:1950-1954.

Thoenen H, Barde YA (1980) Physiology of nerve growth factor. Physiol Rev 60: 1284-1335.

Toran-Allerand CD (1976) Sex steroids and the development of newborn mouse hypothalamus and preoplic areas in vitro: implications for sexual differentiation. Brain Res 106:407-412.

Toran-Allerand CD (1980) Sex steroids and the devclopment of newborn mouse hypothalamus and preoptic area in vitro. II. Morphological correlates and hormonal specificity. Brain Res 189:413-427.

Toran-Allerand CD (1984) On the genesis of sexual differentiation of the central nervous system: morphogenetic consequences of steroidal exposure and possible role of $\alpha$-fetoprolein. Prog Brain Res 61:6398.

Toran-Allerand CD, Miranda RC (1993) Combining non-isotopic in situ hybridization with steroid autoradiography. In: /n simu hybridization in neurobiology, 2d ed (Eberwine J, Barchus J, Valentino K, eds). New York: Oxford UP.

Toran-Allerand CD, Gerlach JL, McEwen BS (1980) Auloradiographic localization of $\left[{ }^{3} \mathrm{H}\right]$ estradio] related to steroid responsiveness in cultures of the newbom mouse hypothalamic and preoptic area. Brain Res 184:517-522.

Toran-Allerand CD, Hashimoto K, Greenough WT, Saltarclli M (1983) Sex steroids and the development of the newborn mouse hypothal- amus and preoptic area in ritro. III. Effects of estrogen on dendritic differentiation. Dev Brain Res 7:97-101.

Toran-Allerand CD, Miranda RC, Bentham W, Sohrabji F, Brown EJ, Hochberg RB, MacLusky NJ (1992a) Estrogen receptor's co-localize with low-affinity NGF receptors in cholinergic neurons of the basal forcbrain. Proc Natl Acad Sci USA 89:4668-4672.

Toran-Allerand CD, Miranda RC, Hochberg RB, MacLusky NJ (1992b) Cellular variations in estrogen receptor mRNA translation in the developing brain: evidence from combined ['s] toradiography and non-isotopic in silu hybridization histochemistry. Brain Res 576:25-4I.

Waterman ML. Adler S. Nelson C, Greenc GL, Evans RM, Rosenfeld MG (1988) A single domain of the estrogen receptor confers deoxyribonucleic acid binding and transcriptional activation of the rat prolactin genc. Mol Endocrinol 2: 14-2!.

Weisz A, Rosales R (1990) Identification of an estrogen response element upstream of the human c-fos gene that binds the cstrogen receptor and the AP.I transcription factor. Nucleic Acids Res 18: $5097-5106$.

Wilcox JN, Roberts JL (1985) Estrogen decreases rat hypothalamic proopiomelanocortin messenger ribonucleic acid levels. Endocrinology 117:2392-2396.

Wright LL, Smolen AJ (1983a) Effects of 17- $\beta$-estradiol on developing superior cervical ganglion neurons and symapses. Dev Brain Res 6:299303.

Wright LL, Smolen AJ (1983b) Nconatal testosterone treatment increases neuron and synapse numbers in male rat superior cervical ganglion. Dev Brain Res 8:145-153.

Wright LL, Marchetti D. Percz-Polo JR (1988) Effects of gonadal steroids on nerve growth factor receptors in sympathetic and sensory ganglia of neonatal rats. Int J Dev Neurosci 6:217-222.

Yan $Q$, Johnson EM (1987) A quantitative study of the developmental expression of nerve growh factor (NGF) receptor in rats. Dev Biol 121:139-148.

Yan Q, Johntson EM (1988) An immunohistochemical study of the nerve growth factor receptor in developing rats. I Neurosci 8:348 13496.

Yu WHA, Gibbs RB, PfafrDW (1991) Effects of testosterone on levets of ribosomal RNA (rRNA) in hypoglossal neurons following nerve injury. Soc Neurosci Abstr 17:226. 